\title{
Sources and dispersal of land-based runoff from small Hawaiian drainages to a coral reef: insights from geochemical signatures
}

Renee K. Takesue ${ }^{\mathrm{a},{ }^{*}}$ and Curt D. Storlazzi ${ }^{\mathrm{b}}$

${ }^{a}$ U.S. Geological Survey, Pacific Coastal and Marine Science Center, 2885 Mission Street, Santa Cruz, CA, 95060 USA, rtakesue@usgs.gov

${ }^{\mathrm{b}}$ U.S. Geological Survey, Pacific Coastal and Marine Science Center, 2885 Mission Street, Santa Cruz, CA, 95060 USA, cstorlazzi@usgs.gov

*corresponding author, rtakesue@usgs.gov, +1-831-460-7594

\begin{abstract}
Land-based sediment and contaminant runoff is a major threat to coral reefs, and runoff reduction efforts would benefit from knowledge of specific runoff sources. Geochemical signatures of small drainage basins were determined in the fine fraction of soil and sediment, then used in the nearshore region of a coral reef-fringed urban embayment on southeast Oahu, Hawaii, to describe sources and dispersal of land-based runoff. The sedimentary rare earth element ratio $(\mathrm{La} / \mathrm{Yb})_{\mathrm{N}}$ showed a clear distinction between the two main rock types in the overall contributing area, tholeiitic and alkalic olivine basalt. Based on this geochemical signature it was apparent that the majority of terrigenous sediment on the reef flat originated from geologically old tholeiitic drainages. Sediment from one of five tholeiitic drainages had a distinct geochemical signature, and sediment with this signature was dispersed on the reef flat $2 \mathrm{~km}$ west and $150 \mathrm{~m}$ offshore of the contributing basin. Sediment and the anthropogenic metals $\mathrm{Cd}, \mathrm{Pb}$, and $\mathrm{Zn}$ were entrained in runoff from the most heavily urbanized region of the watershed. Although
\end{abstract}


anthropogenic $\mathrm{Cd}$ and $\mathrm{Zn}$ had localized distributions close to shore, anthropogenic $\mathrm{Pb}$ was found associated with fine sediment on the westernmost part of the reef flat and $400 \mathrm{~m}$ offshore, illustrating how trade-wind-driven sediment transport can increase the scale of runoff impacts to nearshore communities. Our findings show that sediment geochemical signatures can provide insights about the source and dispersal of land-based runoff in shallow coastal environments. The application of such knowledge to watershed management and habitat remediation efforts can aid in the protection and restoration of runoff-impacted coastal ecosystems worldwide.

Keywords: coral reef, runoff, sediment provenance, rare earth elements, anthropogenic metals; USA, Hawaii, Oahu, Maunalua Bay.

\section{Introduction}

Coastal areas have long been desirable locations for human settlement and economic activity (Mee, 2012). Human use of coastal areas and watersheds can, however, exert a heavy toll on ecosystems by altering natural processes and habitats and overusing resources (Jackson, 2008; Lotze et al., 2006). For example, increased erosion and runoff of sediment, nutrients, and contaminants can degrade coastal water quality and lead to the loss of vital ecosystems including coral reefs (Fabricius, 2005; Pandolfi et al., 2005), seagrasses (Short and Wyllie-Echeverria, 1996; Waycott et al., 2009), and kelp forests (Jackson et al., 2001). Land-based sediment and contaminant runoff is harmful to coral reefs in many ways: it inhibits photosynthesis and larval recruitment, it smothers live corals and exposes them to contaminants, and it is associated with lower live coral cover, lower species diversity, and degraded fisheries (e.g., Fabricius, 2005; Knowlton, 2001; Rogers, 1990). Runoff prevention and control measures in watersheds upstream 
of coral reefs are recognized globally as means to prevent further degradation and facilitate recovery of runoff-impacted coral reefs (e.g., Bartley et al., 2014; Hughes et al., 2010; Richmond et al., 2007). In addition, the coupling of land-based runoff management with an understanding of local hydrodynamic controls on nearshore sediment and contaminant transport is an important component of comprehensive and effective remediation strategies for runoff-impacted reefs (Done, 1995; Hunter and Evans, 1995; Restrepo et al., 2016). Recent studies have demonstrated the use of sediment-geochemical tracers in identifying sources of land-derived sediment to the coastal zone (Araújo et al., 2002; Prego et al., 2012; Prego et al., 2009; Roussiez et al., 2013; Smith et al., 2008). The goals of this study were to identify geochemical signatures of terrigenous sediment and trace metal runoff to a coral reef-fringed urbanized embayment from several short, steep drainages; to use these signatures to identify sediment sources and infer nearshore transport; and to describe the distribution of anthropogenic metals in urbanized basins and the reef flat. The trace metals cadmium $(\mathrm{Cd})$, copper $(\mathrm{Cu})$, lead $(\mathrm{Pb})$, and zinc $(\mathrm{Zn})$ are enriched by anthropogenic activities, particularly the operation of motor vehicles (Alloway, 1995). Insights from geochemical signatures about sources of land-based sediment and contaminants and their nearshore dispersal can help runoff management efforts target priority contributing areas and guide nearshore habitat remediation of sediment-impacted coastal ecosystems.

2. Site description

\subsection{Environmental setting}

Maunalua Bay is an urbanized embayment on the southeast shore of the Island of Oahu, Hawaii, U.S.A. (Fig. 1). Hawaiian watersheds are generally composed of several small, steep 
valleys with streams that enter a larger body of water. Maunalua Bay is one such body, receiving runoff from 10 small drainage basins with a total contributing area of $57 \mathrm{~km}^{2}$. A major highway parallels about half of the shoreline (Fig. 1) and dense residential development occupies the coastal plain, valley floors, and some ridges. Kuapa Pond, a $2 \mathrm{~km}^{2}$ shallow lagoon in the east part of the watershed, was breached permanently, its marshland filled, and developed into the Hawaii Kai Marina complex (Coles et al., 2002). Urban stream sediment and roadside soil in southeast Oahu have been found to contain elevated anthropogenic trace metals (De Carlo et al., 2005; Sutherland and Tolosa, 2000).

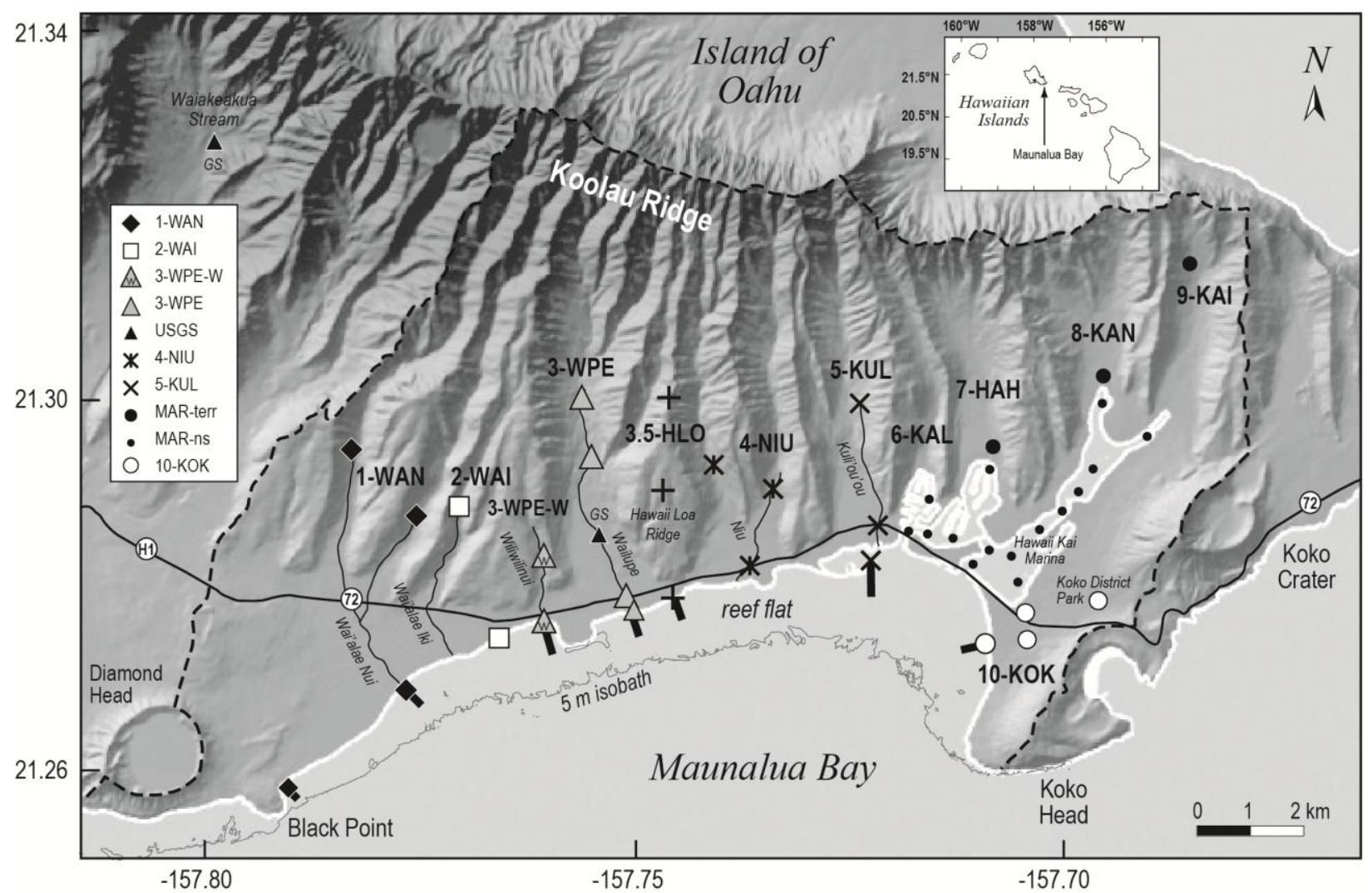

Figure 1. Shaded relief map of southeast Oahu showing Maunalua Bay (white line marks the shoreline) and its watershed (dashed line). Drainage basins are identified with numbers and abbreviations described in Section 3.1. Streams in basins 1-5 are shown by name. The sub-basin 3-WPE-W (Wiliwilinui) is denoted by a 'w' inside a gray 
triangle. Black triangles show USGS gaging stations (GS) on Wailupe and Waiakeakua Streams. 'terr', terrestrial; 'ns', nearshore. Black lines on the reef flat show reef transects. The $5 \mathrm{~m}$ isobath is shown for reference. Inset shows the location of Maunalua Bay in the Main Hawaiian Islands.

Maunalua Bay lies in the lee of Koolau Ridge relative to the direction of the northeast trade winds. Rainfall in the watershed is higher in winter than in summer due to a higher frequency of southerly (Kona) storms and other low pressure disturbances (Giambelluca et al., 2013; Oki and Brasher, 2003). At high elevations on Koolau Ridge where many streams have their headwaters, mean annual rainfall is approximately $1,500-2,000 \mathrm{~mm}$, whereas rainfall on the urbanized coastal plain is about half that amount (Giambelluca et al., 2013; Oki and Brasher, 2003). Sediment retention structures were built in valleys above residential areas to control runoff and stream channels have been straightened and hardened to varying extents. Storm runoff is flashy in nature (Tomlinson and De Carlo, 2003) and exacerbated by the high degree of impervious surface in urban areas (Wolanski et al., 2009).

The Maunalua Bay reef flat ranges from 0.2 to $1.0 \mathrm{~km}$ wide and is approximately $1 \mathrm{~m}$ deep and $10 \mathrm{~km}$ long. It is subject to water quality impairments due to elevated nutrients and chlorophyll, non-native algae, low live coral cover, and diminished fish and seagrass communities (Coles et al., 2002).

Currents in Maunalua Bay are driven by winds and tides (Presto et al., 2012; Storlazzi et al., 2010). At the surface to a depth of $1 \mathrm{~m}$, the prevailing trade winds drive westward transport (Presto et al., 2012), and the corresponding transport of suspended sediment over the reef flat is to the west (Storlazzi et al., 2010). Wind-driven currents are weakest in the eastern part of the bay in the lee of Koko Head and strongest in the middle of the bay offshore of Wailupe Stream (Storlazzi et al., 2010). 


\subsection{Geology}

The uplands around Maunalua Bay consist of layered tholeiitic basalt lava flows from the Makapuu stage of Koolau Volcano (Haskins and Garcia, 2004), which erupted 2-3 Ma (Jackson et al., 1999; Stearns and Vaksvik, 1935). Lava beds dip 4-10 $0^{\circ}$ to the south toward Maunalua Bay (Wentworth and Winchell, 1947). After about a million years of quiescence, subsidence, and erosion of Koolau Volcano (Gramlich et al., 1971), alkalic basalts erupted from rift zones and vents, forming the Honolulu Volcanics. Around Maunalua Bay, rocks of the Honolulu Volcanics form Koko Head, Koko Crater, and Black Point (Clague and Frey, 1982; Stearns and Vaksvik, 1935; Winchell, 1947) (Fig. 1). Mantle-incompatible trace element contents of Makapuu stage lavas can vary widely (Huang and Frey, 2005) but do not vary systematically with age (Jackson et al., 1999). Compared to Koolau basalt, rocks of the Honolulu Volcanics are enriched in alkali and alkali earth elements, light rare earth elements, and incompatible trace elements (Clague and Frey, 1982; Roden et al., 1984).

\section{Approach}

The element aluminum (Al) is a major component of terrestrial sediment (Windom et al., 1989) and a trace component of marine carbonates (Milliman and Syvitski, 1992). This ordersof-magnitude difference makes $\mathrm{Al}$ a sensitive indicator of terrigenous sediment in environments where carbonate sediment predominates. In other coastal environments, Al contents of coastal sediment have been used to indicate riverine sediment inputs in the Gulf of Papua (Brunskill et al., 1995) and the Portuguese shelf (Araújo et al., 2002). Furthermore, Al is not generally 
enriched by anthropogenic activities (Windom et al., 1989) nor is it altered by oxidationreduction processes as is the element iron $(\mathrm{Fe})$, another major component of basalt.

To characterize geochemical signatures of drainages contributing sediment to Maunalua Bay, immobile and relatively immobile trace element contents were determined in the fine fraction of stream sediment, where possible, to exploit the integrative nature over space and time of sediment stored in streams (Frissell et al., 1986). Rare earth elements (REE), scandium (Sc), and thorium (Th) are the most effective sediment provenance indicators (McLennan, 1989; McLennan et al., 1993). Barium (Ba), chromium (Cr), cobalt (Co), nickel (Ni), niobium ( $\mathrm{Nb}$ ), rubidium $(\mathrm{Rb})$, and zirconium $(\mathrm{Zr})$ are can also be informative but could be affected by sorting and weathering (McLennan et al., 1993). The anthropogenic trace metals cadmium (Cd), copper $(\mathrm{Cu})$, lead $(\mathrm{Pb})$, and zinc $(\mathrm{Zn})$ were explored as urban overprints on sediment geochemistry in drainage basins surrounding Maunalua Bay and on the reef flat.

\subsection{Sediment collection}

A low degree of fine-grained sediment storage in the short, hardened stream channels around Maunalua Bay in many cases necessitated sediment collection from retention basins and from features such as culverts on the urbanized coastal plain. The upper $1-3 \mathrm{~cm}$ of sediment, where possible, composed of redeposited soil and organic matter were collected in catchments $7-$ 10 June 2010 using acid-cleaned polypropylene sampling tools. Culverts generally contained only a veneer of sediment. In situ soil was collected from Hawaii Loa Ridge to address the local perception that construction activities made it a source of runoff to the reef. The lower reaches of Wailupe, Niu, and Kuli'ou'ou Streams were sampled from highway bridges, and marina bottom sediment from a small boat, using a hand-deployed Petite Ponar ${ }^{\circledR}$ benthic sampler. The upper 0- 
$5 \mathrm{~cm}$ of seabed sediment on the reef flat was collected by hand at low tide in acid-cleaned polypropylene jars along shore-normal transects offshore of Black Point, Wai'alae Nui Stream, Wiliwilinui Stream, Wailupe Stream, Hawaii Loa Ridge, Kuli'ou'ou Stream, and Portlock at distances of $0,50,100,250$, and $400 \mathrm{~m}$, where possible. Sampling locations and the numbers of samples are shown in Figure 1 and Table 1.

The 10 small basins that drain to Maunalua Bay and Hawaii Loa Ridge are for convenience denoted with numbers increasing from west to east and an abbreviation: Wai'alae Nui (1-WAN), Wai'alae Iki (2-WAI), Wailupe (3-WPE), which includes Wiliwilinui (3-WPEW), Hawaii Loa Ridge (3.5-HLO), Niu (4-NIU), Kuli'ou'ou (5-KUL), Ka'alakei (6-KAL), Haha'ione (7-HAH), Kamilo Nui (8-KAN), Kamilo Iki (9-KAI), and Portlock (10-KOK) (Fig. 1, Table 1). Runoff from 6-KAL, 7-HAH, 8-KAN, and 9-KAI enters the Hawaii Kai Marina (MAR) and can become trapped there until removal from the system by dredging. Because the linkage between runoff into the marina and discharge into Maunalua Bay may be weak, sediment geochemistry from these basins and the marina will not be discussed in detail.

Table 1. Drainage basin codes, names, area estimates, numbers of samples, and numbers of rare earth element (REE) analyses in the Maunalua Bay watershed.

\begin{tabular}{|c|c|c|c|c|c|c|}
\hline \multirow[b]{2}{*}{ Basin code } & \multirow[b]{2}{*}{ Basin name } & \multirow{2}{*}{$\begin{array}{c}\text { Drainage area } \\
\left(\mathrm{km}^{2}\right)^{1}\end{array}$} & \multicolumn{2}{|c|}{ Number of samples } & \multicolumn{2}{|c|}{ Number of REE analyses } \\
\hline & & & Terrestrial & Nearshore $^{2}$ & Terrestrial & Nearshore \\
\hline 1-WAN & Wai'alae Nui & 11.2 & 5 & 7 & 5 & 3 \\
\hline 2-WAI & Wai'alae Iki & 4.6 & 2 & 2 & 2 & 1 \\
\hline 3-WPE-W & Wiliwilinui $^{3}$ & 1.0 & 2 & 7 & 2 & 6 \\
\hline 3-WPE & Wailupe & 9.5 & 4 & 6 & 3 & 2 \\
\hline 3.5-HLO & Hawaii Loa Ridge & 0.7 & 4 & 4 & 4 & 3 \\
\hline 4-NIU & $\mathrm{Niu}$ & 7.4 & 5 & 1 & 5 & 1 \\
\hline 5-KUL & Kuli'ou'ou & 4.7 & 3 & 7 & 2 & 6 \\
\hline MAR & Marina $^{4}$ & 16.0 & 2 & 17 & 2 & 17 \\
\hline 10-KOK & Portlock & 1.8 & 4 & 4 & 4 & 2 \\
\hline
\end{tabular}


${ }^{1}$ Estimates from ridge to shoreline from Google Earth Pro

${ }^{2}$ Nearshore includes estuarine sites

${ }^{3}$ Wiliwilinui is included in Wailupe

${ }^{4}$ Marina drainages include Ka'alakei, Haha'ione, Kamilo Nui, Kamilo Iki

\subsection{Sediment geochemical analyses}

Geochemical analyses were performed on the sediment fine fraction (particle diameter $<63 \mu \mathrm{m})$ to reduce grain size bias among samples. Bulk sediment was dried at $60^{\circ} \mathrm{C}$, disaggregated gently to preserve original grains in an acid-cleaned agate mortar and pestle, and dry-sieved using stainless steel sieves to obtain the $<63 \mu \mathrm{m}$ fraction. Fine sediment was decomposed according to EPA Method 3052, a near-total microwave-assisted digestion of siliceous matrices using hydrochloric and hydrofluoric acids (USEPA, 1996). Contents of major, minor, and trace elements including $\mathrm{Al}, \mathrm{Ba}, \mathrm{Ca}, \mathrm{Cd}, \mathrm{Co}, \mathrm{Cu}, \mathrm{Fe}, \mathrm{K}, \mathrm{Mg}, \mathrm{Mn}, \mathrm{Na}, \mathrm{Pb}, \mathrm{Sr}, \mathrm{Ti}, \mathrm{V}$, and $\mathrm{Zn}$ were determined on a ThermoFinnigan Element I High Resolution inductively-coupled plasma mass spectrometer (ICP-MS) at the Marine Analytical Laboratories of the University of California at Santa Cruz. Internal standardization was with germanium $\left({ }^{72} \mathrm{Ge}\right)$; external standardization was with sediment reference materials (SRMs): National Institute of Standards and Technology 1646a and 2702 and Canadian Certified Reference Materials Stream Sediment 2 and 3. The reproducibility, expressed by the relative standard deviation (RSD) of a consistency standard analyzed five times, was $6 \%$ or better for all target elements except strontium (Sr) which had a RSD of $10 \%$. The reproducibility of Fe measurements was better than $3 \%$. Contents of target elements in 86 soil and sediment samples analyzed on the Element I were several orders of magnitude higher than analytical detection limits, which were defined as three times the standard deviation of blanks. Contents of rare earth elements (REE), elements in resistant 
minerals (Cr, Hf, $\mathrm{Nb}, \mathrm{Y}, \mathrm{Zr}$ ); elements with inadequate external standards ( $\mathrm{La}, \mathrm{Rb}, \mathrm{Th})$; and nickel (Ni) and scandium (Sc), which may have had molecular interferences, were obtained by total digestion of 70 samples that had sufficient fine material for quantification by SGS Inc., a nationally-recognized testing laboratory. SGS used a sodium peroxide sinter for total digestion and quantified major and minor elements by ICP-AES (atomic emission) and trace elements by ICP-MS. The reproducibility of three replicate samples analyzed by SGS was better than 10\% for all target elements except the rare earth element thulium (Tm), which had a reproducibility of $12 \%$. Target element contents determined by SGS were five or more times higher than analytical detection limits. Major element contents are reported as weight percent (wt \%) and minor and trace element contents as micrograms per gram $(\mu \mathrm{g} / \mathrm{g})$. Geochemical data are tabulated in the supplementary material.

\subsection{Normalization and criteria for geochemical signatures}

Elemental contents of fine sediment were normalized to iron (Fe) to account for basaltic parent rock compositions, a convention used in Hawaiian soil and sediment (e.g., De Carlo and Spencer, 1995) because it can contain primary volcanic minerals (Nelson et al., 2013). REE contents were normalized to a North American shale composite (NASC), which represents the composition of average sedimentary rock (McLennan, 1989). Normalized values are denoted with subscripts $\mathrm{M}_{\mathrm{Fe}}$ or $\mathrm{REE}_{\mathrm{N}}$. Statistics were calculated with StatPlus:mac Pro software. REE ratios were normally distributed in basaltic and in alkalic fine sediment (Shapiro-Wilk). Analysis of variance (ANOVA) was performed on log-transformed data for non-normally distributed parameters. 
Geochemical tracers used for sediment-source attribution should vary little within each source region so that end members are well-constrained, and considerably among source regions to allow discrimination (Collins and Walling, 2002). Ratios of 29 major and trace elements relative to $\mathrm{Al}, \mathrm{Fe}, \mathrm{Nb}, \mathrm{Sc}$, and $\mathrm{Th}$, and seven $\mathrm{REE}$ ratios were examined in the initial data review. A high degree of chemical weathering has been observed in Hawaiian soil and suggests that only immobile element ratios are representative of source compositions (Kurtz et al., 2000; Vitousek et al., 1997). Accordingly, further data exploration focused on immobile elements (REE ratios,

$\left.\mathrm{Sc}_{\mathrm{Fe}}, \mathrm{Th}_{\mathrm{Fe}}\right)$ and relatively immobile elements $\left(\mathrm{Ba}_{\mathrm{Fe}}, \mathrm{Cr}_{\mathrm{Fe}}, \mathrm{Co}_{\mathrm{Fe}}, \mathrm{Ni}_{\mathrm{Fe}}, \mathrm{Nb}_{\mathrm{Fe}}, \mathrm{Rb}_{\mathrm{Fe}}, \mathrm{Zr}_{\mathrm{Fe}}\right)$ as potential geochemical signatures in sediment derived from the two types of basalt in the Maunalua Bay watershed, henceforth denoted by THO (sediment derived from tholeiitic basalt, $\mathrm{n}=25$ ) and AOB (sediment derived from alkalic olivine basalt, $\mathrm{n}=4$ ). One criterion was that the geochemical property should have low coefficients of variation $(\mathrm{CV}$, defined as ratio of the standard deviation to the mean) in $\mathrm{AOB}$ and $\mathrm{THO}$. The other was that the geochemical property should have a large enrichment factor (EF) between $\mathrm{AOB}$ and THO. EFs were calculated as the ratios of median values $\left(\mathrm{EF}=\operatorname{median}_{\mathrm{AOB}} / \operatorname{median}_{\mathrm{THO}}\right)$. A conservative value of 2 was used for the minimum $\mathrm{EF}$ criterion, which yielded geochemical signatures that were on average two or more times higher in AOB than THO. EFs of immobile and relatively immobile elements in AOB and THO were plotted relative to the corresponding CVs in order to identify the most effective geochemical tracers.

\subsection{Environmental data}

Time series of daily stream discharge and total suspended sediment concentration were obtained from USGS gaging station 16247550 (Wailupe Gulch at E. Hind Drive Bridge) for the 
two years preceding the study. Annual stream discharge at station 16240500 (Waiakeakua Stream at the head of nearby Manoa Valley) over the past three decades provided a long-term context for southeast Oahu. Wind data were obtained from NOAA National Ocean Service (NOS) Station 1612340 (Honolulu, Hawaii), approximately $15 \mathrm{~km}$ west of Maunalua Bay.

\section{Results}

\subsection{Environmental conditions}

In the 8 months preceding this study, northeast trade winds were prevalent $55 \%$ of the time and there were only $16 \mathrm{~d}$ when the mean daily wind direction was from the west (Fig 2). Water year (WY) 2010, which began 1 October 2009, was a dry year. Honolulu received about half the amount of precipitation as in the preceding year (Presley and Jamison, 2010). Discharge in Wailupe Stream was four times lower than in WY 2009, and discharge in Waiakekua Stream was four times lower than the decadal average (Oki and Brasher, 2003). 

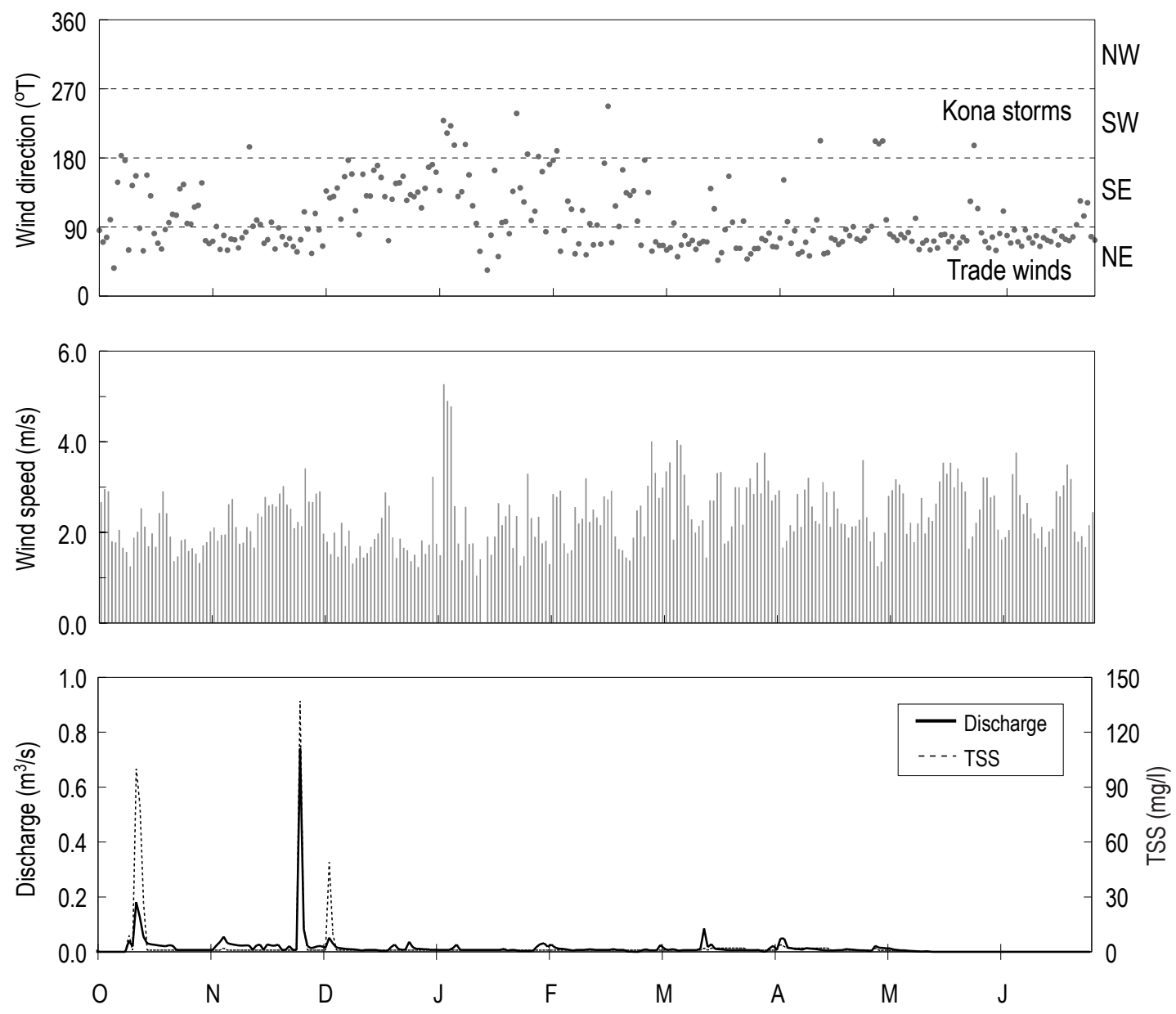

Figure 2. Time series plots of wind direction (top) and wind speed (middle) at NOS Meteorological Station 1612340 in Honolulu. Bottom panel shows stream discharge and total suspended sediment concentration (TSS) in Wailupe Stream at USGS gaging station 16247550 from 1 October 2009 through 30 June 2010.

\subsection{Terrigenous sediment on the reefflat}

Aluminum contents of fine-grained sediment on the reef flat ranged from $0.6-6.6 \mathrm{wt} \%$ with a mean of $2.7 \pm 1.5 \mathrm{wt} \%(1 \sigma)$ compared to a mean of $9.8 \pm 1.2 \mathrm{wt} \%(1 \sigma)$ in fine-grained upland sediment. Assuming fine sediment on the reef flat was a mixture primarily of terrigenous and carbonate material, and that the $\mathrm{Al}$ content of terrigenous sediment on the reef flat was similar to that of upland sediment, then $6-66 \%$ (mean of $27 \%$ ) of fine sediment on the reef flat was land-derived. Fine-sediment Al contents generally decreased with distance from shore, 
except offshore of Wiliwilinui and Portlock, where Al maxima occurred at $50 \mathrm{~m}$. The three nearshore sites with the largest fractions of terrigenous sediment based on their Al contents were, in decreasing order: the mouth of Wailupe Stream (66\%), $50 \mathrm{~m}$ offshore of Wiliwilinui Stream (58\%), and the mouth of Kuli'ou'ou Stream (44\%). At two reef sites $400 \mathrm{~m}$ from the shore, the fine fraction of bed sediment contained only $1.2 \%$ and $1.4 \%$ terrigenous material.

\subsection{Geochemical signatures}

Fine-sediment contents of $\mathrm{Sc}_{\mathrm{Fe}}, \mathrm{Cr}_{\mathrm{Fe}}, \mathrm{Co}_{\mathrm{Fe}}, \mathrm{Ni}_{\mathrm{Fe}}$, and $\mathrm{Zr}_{\mathrm{Fe}}$ were relatively similar in $\mathrm{AOB}$ and THO $(0.8<\mathrm{EF}<1.3$, Fig. 3$)$ and so were not investigated further as geochemical signatures. $\mathrm{Rb}_{\mathrm{Fe}}$ had $\mathrm{EF}=10.2$, however its high $\mathrm{CV}$ s precluded its ability to constrain end member compositions (Fig. 3). The median $\mathrm{Ba}_{\mathrm{Fe}}$ value was almost five times higher in $\mathrm{AOB}$ relative to THO and its CVs were intermediate (Fig. 3). EF values for $(\mathrm{La} / \mathrm{Yb})_{\mathrm{N}}, \mathrm{Nb}_{\mathrm{Fe}}$, and $\mathrm{Th}_{\mathrm{Fe}}$ were 2.4, 2.5, and 2.4, respectively (Fig. 3). Because (La/Yb) $)_{\mathrm{N}}$ had the lowest $\mathrm{CVs}$ and $\mathrm{EF}>2$ (Fig. 3), it was selected as the geochemical signature by which sources of land-based fine sediment to Maunalua Bay were evaluated. 


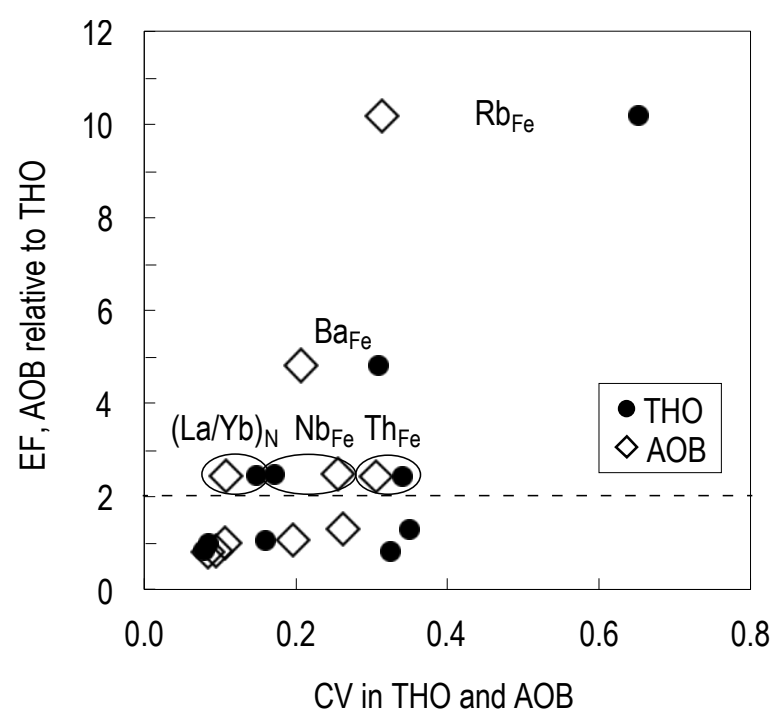

Figure 3. Comparisons of enrichment factors $(\mathrm{EF})$ of Fe-normalized immobile and relatively immobile elements in the fine fraction of terrestrial soil and sediment derived from tholeiitic (THO) and alkalic olivine basalt (AOB) relative to their coefficients of variation $(\mathrm{CV})$. Circles show groupings for THO and AOB corresponding to the labeled element. Dashed line shows $\mathrm{EF}=2$. Symbols below the line are for $\mathrm{Sc}_{\mathrm{Fe}}, \mathrm{Cr}_{\mathrm{Fe}}, \mathrm{Co}_{\mathrm{Fe}}, \mathrm{Ni}_{\mathrm{Fe}}$, and $\mathrm{Zr}_{\mathrm{Fe}}$.

$(\mathrm{La} / \mathrm{Yb})_{\mathrm{N}}$ ratios in THO and AOB fell along distinctly different trends (Fig. 4). Fine sediment at 31 of 36 reef sites had $(\mathrm{La} / \mathrm{Yb})_{\mathrm{N}}$ compositions that more closely followed the trend of tholeiitic basalt than alkalic olivine basalt (Fig. 4). An estuarine sample collected in Niu Stream (4-NIU) had a $(\mathrm{La} / \mathrm{Yb})_{\mathrm{N}}$ ratio indicative of an AOB source whereas Niu basin consisted of tholeiitic basalt. Stream sediment in Wiliwilinui basin (3-WPE-W) had elevated $\mathrm{La}_{\mathrm{N}}$ contents relative to $\mathrm{Yb}_{\mathrm{N}}$ values $\left(\mathrm{La}_{\mathrm{N}}=0.5-0.6\right)$, representing an enrichment of $0.1-0.2$ units relative to 3WPE sediment (Fig. 4); this difference was significant in a one-way ANOVA $(p=0.02)$. This enrichment is also apparent at five sites on the reef flat: $0 \mathrm{~m}$ and $50 \mathrm{~m}$ offshore of the mouth of Wiliwilinui Stream (3-WPE-W), at the shoreline of 2-WAI, and at the shoreline and $150 \mathrm{~m}$ offshore of 1-WAN (Fig. 4). 


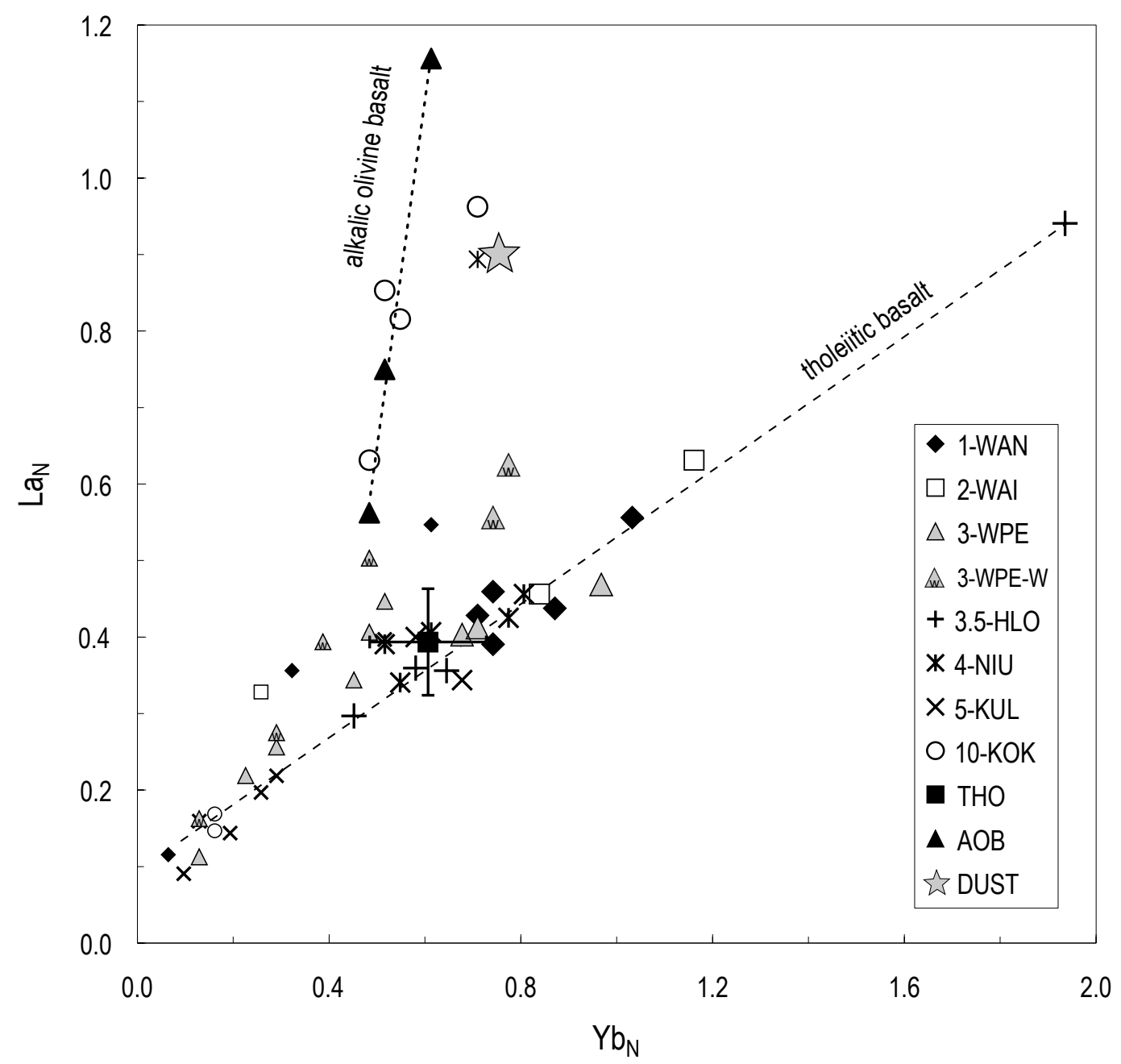

Figure 4. Plot of fine-sediment lanthanum $\left(\mathrm{La}_{\mathrm{N}}\right)$ relative to ytterium $\left(\mathrm{Yb}_{\mathrm{N}}\right)$ contents in terrestrial (large symbols) and marine environments (small symbols). The average composition and standard deviation (error bars) of tholeiitic basalt (THO) are shown for reference, data from Frey et al. (1994). The dashed line shows the least-squares regression through $\mathrm{HLO}(r=0.9980, \mathrm{n}=4)$ extrapolated from $\mathrm{Yb}_{\mathrm{N}}=0.5$ to low $\mathrm{Yb}_{\mathrm{N}}$ values. The compositions of alkalic olivine basalts (AOB) are shown for reference, data from Clague and Frey (1982) with a least-squares regression line ( $r=0.9949, \mathrm{n}=3$, dotted line). The star shows the composition of Asian dust in North Pacific pelagic sediment near Hawaii (Nakai et al., 1993).

Stream sediment from tholeiitic basins 1-5 and soil from Hawaii Loa Ridge could not be distinguished individually based on their $(\mathrm{La} / \mathrm{Yb})_{\mathrm{N}}$ ratios, except for Wiliwilinui. Instead, $\mathrm{Ba}_{\mathrm{Fe}}$, $\mathrm{Nb}_{\mathrm{Fe}}$, and $\mathrm{Th}_{\mathrm{Fe}}$ were examined as potential basin-specific geochemical signatures because these 
immobile or relatively immobile elements were more variable among tholeiitic fine sediment. There were 2 to 5 samples from individual source areas (Table 1). The fine fraction of soil and sediment from basins 1-5 and Hawaii Loa Ridge had generally similar median $\mathrm{Ba}_{\mathrm{Fe}}$ and $\mathrm{Nb}_{\mathrm{Fe}}$ values with the exception of $\mathrm{Nb}_{\mathrm{Fe}}$ at Wiliwilinui (Fig. 5). Median $\mathrm{Th}_{\mathrm{Fe}}$ contents of fine sediment appeared to be slightly lower in basins 1 and 2 compared to Hawaii Loa Ridge and basins 4, 5 (Fig. 5). However, log-transformed $\mathrm{Ba}_{\mathrm{Fe}}, \mathrm{Nb}_{\mathrm{Fe}}$, and $\mathrm{Th}_{\mathrm{Fe}}$ contents of fine sediment were statistically indistinguishable among individual tholeiitic basins except for $\mathrm{Nb}_{\mathrm{Fe}}$ at Wiliwilinui (one-way ANOVA with Fisher LSD post-hoc analysis for $p<0.01$ ), as were other commonly used sediment provenance indicators such as log-transformed $\mathrm{La} / \mathrm{Th}, \mathrm{Th} / \mathrm{Sc}$, and $\mathrm{Sm} / \mathrm{Nd}$ and $\mathrm{Eu} / \mathrm{Eu}^{*}$. Thus, except in the case of Wiliwilinui, it was not possible to geochemically discriminate sediment from individual tholeiitic basins and Hawaii Loa Ridge based on this set of samples and these geochemical parameters. This result was not wholly unexpected because immobile elements were found to covary in Makapuu stage lavas (Huang and Frey, 2005).
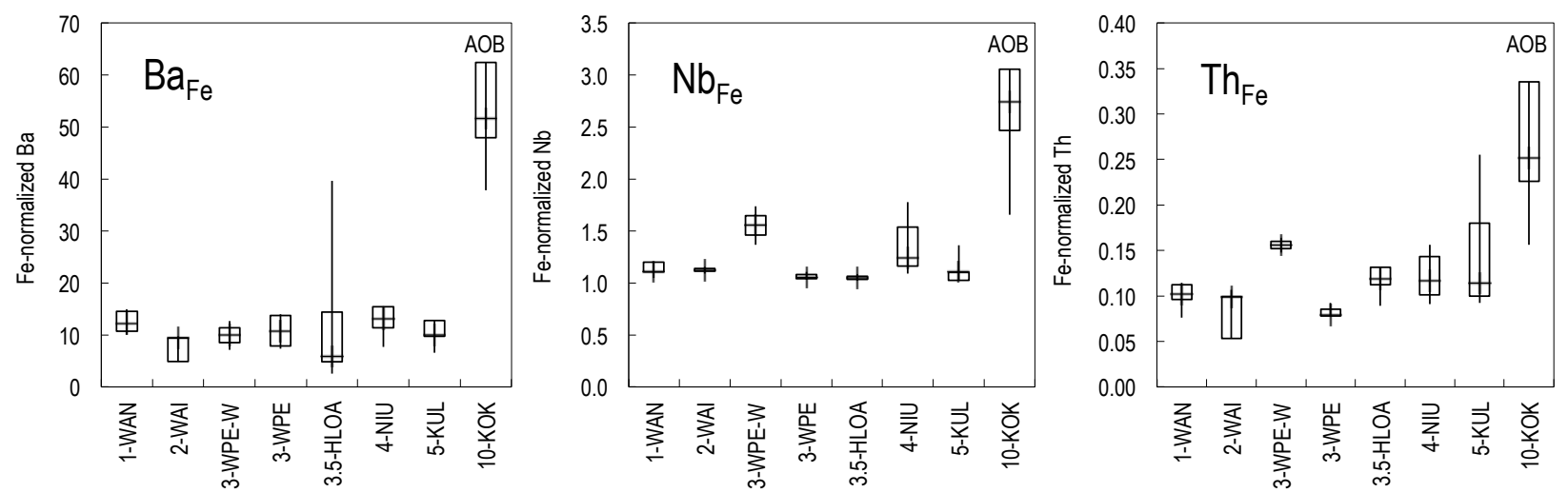

Figure 5. Box and whisker plots of Fe-normalized barium (Ba), niobium $(\mathrm{Nb})$, and thorium $(\mathrm{Th})$ contents of finesediment from five tholeiitic basins (1-5) and Hawaii Loa Ridge (3.5). The height of the box shows the interquartile range, the whiskers show the maximum and minimum values, and the line crossing the whiskers shows the median value. The composition of sediment derived from alkalic olivine basalt (AOB) in 10-KOK is shown for comparison. 


\subsection{Geochemical inputs to soil from Asian dust}

Dust from Asia is transported in the atmosphere across the North Pacific Ocean and deposited on the land surface of Hawaii (Dymond et al., 1974; Rex et al., 1969) where it can be incorporated in soil (Kurtz et al., 2001; Porder et al., 2007). Because the chemical composition of Asian dust can differ substantially from that of Hawaiian soil (e.g., Ferrat et al., 2011; Nakai et al., 1993), it can alter geochemical mass balances in the soil column (Kurtz et al., 2001; Vitousek et al., 1997). Dust deposition is associated with orographic rainfall and thus varies spatially and with elevation on Oahu (Jackson et al., 1971). In the contributing area of Maunalua Bay, dust deposition should be greater at high elevations than on the coastal plain and in western drainages compared to eastern ones (Giambelluca et al., 2013). Following the approach of Kurtz et al. (2001) who used soil $\mathrm{Th} / \mathrm{Nb}$ ratios to estimate the Asian dust contribution to soil on the Island of Hawaii, the fine fraction of soil and sediment collected for this study was estimated to contain 0$15 \%$ Asian dust, assuming $\mathrm{Th} / \mathrm{Nb}$ ratios of 0.52 for Asian dust (Kurtz et al., 2001), 0.05 for Koolau basalt (Frey et al., 1994), and 0.08 for alkali olivine basalt and basanite (Clague and Frey, 1982). One sample from 5-KUL had an elevated $\mathrm{Th}$ content and $\mathrm{Th} / \mathrm{Nb}$ ratio that yielded an estimated dust contribution of $36 \%$, but its $(\mathrm{La} / \mathrm{Yb})_{\mathrm{N}}$ ratio was not indicative of a large dust fraction so it was considered an outlier and disregarded. The mean $\pm 1 \sigma$ estimated dust content was lowest at $10-\mathrm{KOK}(4 \pm 2 \%)$, the driest and easternmost basin, and highest on Hawaii Loa Ridge (12 $\pm 4 \%$ ), the highest elevation site. There were no other longitudinal patterns in the mean estimated dust content of fine sediment in drainage basins surrounding Maunalua Bay: 1-WAN

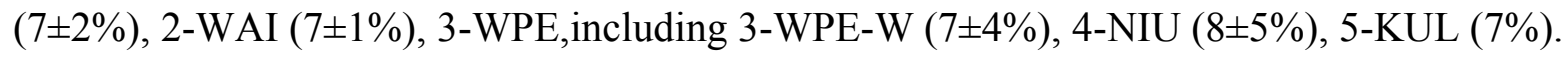


Wiliwilinui (3-WPE-W) was the only basin whose sediment had $(\mathrm{La} / \mathrm{Yb})_{\mathrm{N}}$ ratios that were intermediate between those of $\mathrm{AOB}$ and THO (Fig. 5). Asian dust $\left[(\mathrm{La} / \mathrm{Yb})_{\mathrm{N}}=1.22\right.$, (Nakai et al., 1993)] would increase the $(\mathrm{La} / \mathrm{Yb})_{\mathrm{N}}$ ratio of soil developed on THO [0.67, (Frey et al., 1994)] and decrease the $(\mathrm{La} / \mathrm{Yb})_{\mathrm{N}}$ ratio of soil developed on AOB [1.50, (Clague and Frey, 1982)]. Based on the percentages of Asian dust estimated from the $\mathrm{Th} / \mathrm{Nb}$ ratios of two samples from Wiliwilinui Stream, 7\% and 14\%, Asian dust inputs could explain approximately half of the increase of $(\mathrm{La} / \mathrm{Yb})_{\mathrm{N}}$ ratios relative to THO in 3-WPE-W.

In the nearshore region, fine sediment with elevated $(\mathrm{La} / \mathrm{Yb})_{\mathrm{N}}$ ratios relative to $\mathrm{THO}$ were observed at the highway bridge over Niu Stream and to the west of 3-WPE-W. No sediment in Niu basin had similarly elevated values, making it likely that the higher ratio reflected the presence of AOB rather than Asian dust. Estimated dust contents of nearshore fine sediments were insufficient to account for elevated $(\mathrm{La} / \mathrm{Yb})_{\mathrm{N}}$ ratios offshore of 3-WPE-W, but could possibly account for those offshore of 1-KAN and 2-KAI.

\subsection{Trace metals}

Chromium and Ni contents of Maunalua Bay terrestrial, estuarine, and reef fine sediment and soil were correlated with those of Fe (Fig. 6). Nickel contents relative to Fe fell along a linear trend for all basins and depositional environments, whereas $\mathrm{Cr}$ contents fell into two populations, one with $\mathrm{Cr}$ contents that increased with increasing $\mathrm{Fe}$, and one with low $\mathrm{Cr}$ and high Fe contents (Fig. 6). All terrestrial soil and sediment had $\mathrm{Cr}$ contents that exceeded the probable effects concentration (PEC) for freshwater ecosystems, $111 \mu \mathrm{g} / \mathrm{g}$ (MacDonald et al., 2000), as did 24 for $\mathrm{Ni}$ [PEC $=48.6 \mu \mathrm{g} / \mathrm{g}$, (MacDonald et al., 2000)]. At 25 marine and estuarine sites sediment had $\mathrm{Cr}$ contents that exceeded the level at which adverse biological effects are 
probable in marine and estuarine environments [ERM, $370 \mu \mathrm{g} / \mathrm{g}$ (Long et al., 1995)], as did 42 with respect to $\mathrm{Ni}(51.6 \mu \mathrm{g} / \mathrm{g}$, Fig. 6). The sites with the highest $\mathrm{Cr}$ contents in fine-grained sediment were nearshore sites: Wiliwilinui (3-WPE-W) stream mouth $(0 \mathrm{~m})$ and $50 \mathrm{~m}$ offshore of the stream mouth, and a storm drain $125 \mathrm{~m}$ to the west of Wiliwilinui stream that carried runoff from Wailupe basin.
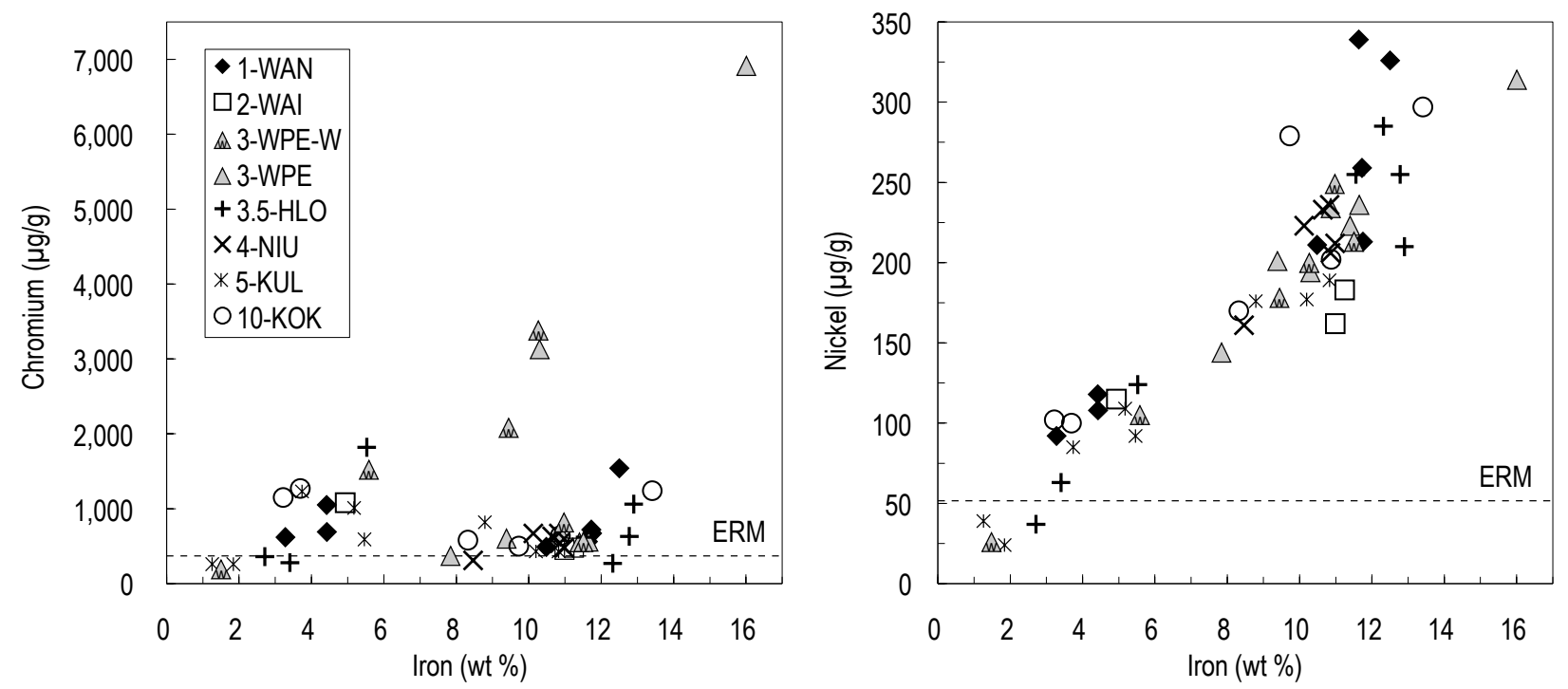

Figure 6. Plots of chromium and nickel content relative to iron content for all samples. The dashed lines show the effects range median values (ERM) for reference.

Among terrestrial soil and sediment samples collected in June 2010, approximately twice as many had $\mathrm{Cu}$ and $\mathrm{Pb}$ contents exceeding background levels determined in forested conservation lands during the 1998-2000 National Water Quality Assessment on Oahu than for $\mathrm{Cd}$ and $\mathrm{Zn}$ (Table 2). Trace metal enrichments were up to $6(\mathrm{Cd}), 1.8(\mathrm{Cu}), 65(\mathrm{~Pb})$, and $6(\mathrm{Zn})$ times background levels in fine soil and sediment in the contributing area of Maunalua Bay; however, median fine-sediment contents of $\mathrm{Cd}, \mathrm{Cu}, \mathrm{Pb}$, and $\mathrm{Zn}$ were at or below background 
levels (Table 2). Soil and sediment with elevated $\mathrm{Cd}, \mathrm{Cu}$, and $\mathrm{Zn}$ generally occurred on land, whereas more marine sites had above-background $\mathrm{Pb}$ contents than terrestrial ones (Table 2).

Table 2. Levels of anthropogenic trace metals in unimpacted areas, sediment quality criteria, and in Maunalua Bay terrestrial and marine (reef and estuarine) sediment.

\begin{tabular}{|c|c|c|c|c|}
\hline & $C d(p p m)$ & $\mathrm{Cu}(\mathrm{ppm})$ & $\mathrm{Pb}(\mathrm{ppm})$ & $Z n(p p m)$ \\
\hline \multicolumn{5}{|l|}{ Background levels in unimpacted areas } \\
\hline Upland forested soil ${ }^{1}$ & $0.20 \pm 0.08$ & $223 \pm 17$ & $5 \pm 3$ & $210 \pm 27$ \\
\hline Estuarine sediment, Ala Wai Canal ${ }^{2}$ & $0.29 \pm 0.03$ & $141 \pm 6$ & $14 \pm 1$ & $122 \pm 11$ \\
\hline \multicolumn{5}{|l|}{ Freshwater sediment quality criteria ${ }^{3}$} \\
\hline Threshold effects concentration (TEC) & 0.99 & 31.6 & 35.8 & 121 \\
\hline Probable effects concentration (PEC) & 4.98 & 149 & 128 & 459 \\
\hline \multicolumn{5}{|l|}{ Marine and estuarine sediment quality criteria ${ }^{4}$} \\
\hline Effects range low (ERL) & 1.2 & 34 & 46.7 & 150 \\
\hline Effects range median (ERM) & 9.6 & 270 & 218 & 410 \\
\hline \multicolumn{5}{|l|}{ Terrestrial sediment, June $2010(n=31)$} \\
\hline Minimum & 0.10 & 126 & 3 & 113 \\
\hline Maximum & 1.16 & 391 & 325 & 1253 \\
\hline Median & 0.18 & 218 & 5 & 167 \\
\hline Mean & 0.24 & 215 & 23 & 219 \\
\hline Standard deviation & 0.19 & 50 & 61 & 208 \\
\hline \# samples exceeding upland background & 6 & 13 & 14 & 5 \\
\hline \multicolumn{5}{|l|}{ Reef and estuarine sediment, June $2010(n=55)$} \\
\hline Minimum & 0.04 & 17 & 3 & 18 \\
\hline Maximum & 2.36 & 262 & 114 & 292 \\
\hline Median & 0.09 & 78 & 15 & 86 \\
\hline Mean & 0.14 & 90 & 21 & 104 \\
\hline Standard deviation & 0.31 & 55 & 21 & 56 \\
\hline \# samples exceeding estuarine background & 1 & 11 & 29 & 17 \\
\hline
\end{tabular}

${ }^{1}$ De Carlo et al. (2005), leeward sites $(n=4)$

${ }^{2}$ De Carlo and Spencer (1995), core G8B (107-110 cm, n=3)

${ }^{3}$ Consensus-based values from MacDonald et al. (2000)

${ }^{4}$ Long et al. (1995)

Two of 31 terrestrial sites had $\mathrm{Pb}(1$ site $)$ and $\mathrm{Zn}$ ( 2 sites $)$ contents of fine sediment that exceeded the PEC (Table 2). These were culverts adjacent to a major highway on the south shore of Hawaii Kai Marina and Koko District Park. Runoff near the highway had the highest Zn and 
$\mathrm{Pb}$ contents measured in this study $(1,253 \mu \mathrm{g} / \mathrm{g}$ and $325 \mu \mathrm{g} / \mathrm{g}$, respectively). The $\mathrm{Cu}$ background level in Maunalua soil was three times higher than the PEC (Table 2), and all but three terrestrial sites had soil or sediment $\mathrm{Cu}$ contents of the fine fraction that exceeded the PEC. The highest overall $\mathrm{Cu}$ value $(391 \mu \mathrm{g} / \mathrm{g})$ was measured in forested parkland on Hawaii Loa Ridge at $340 \mathrm{~m}$ elevation. At no sites did soil or sediment Cd contents of the fine fraction exceed the PEC, which was more than an order of magnitude higher than the Cd background in Maunalua soil (Table 2). In the nearshore region, $\mathrm{Cd}, \mathrm{Cu}$, and $\mathrm{Zn}$ were elevated above estuarine background levels in fine sediment deposited in estuarine reaches of streams, in marina bottom sediment, at the land-sea interface, and up to $75 \mathrm{~m}$ from shore offshore of Wai'alae Nui and Wiliwilinui streams. All nearshore fine-sediment contents of $\mathrm{Cd}, \mathrm{Cu}, \mathrm{Pb}$, and $\mathrm{Zn}$ were below marine and estuarine ERM levels. Pb was the only anthropogenic trace metal that was consistently elevated above background levels in estuarine and reef flat fine sediment. Total $\mathrm{Pb}$ contents ranged from 3-114 $\mu \mathrm{g} / \mathrm{g}$ (Fig. 7) compared to an estuarine background of $14 \pm 1 \mu \mathrm{g} / \mathrm{g}$ (Table 2). When normalized to Fe to account for $\mathrm{Pb}$ in the geologic fraction, patterns of $\mathrm{Pb}$ enrichment were less extreme closer to shore (Fig. 7), and the highest $\mathrm{Pb}_{\mathrm{Fe}}$ value was found in carbonate-dominated sediment $400 \mathrm{~m}$ offshore of Wiliwilinui (3-WPE-W). The $\mathrm{Pb}_{\mathrm{Fe}}$ ratio of that sample, 52, was similar to the ratio in estuarine sediment before the phase-out of leaded gasoline (De Carlo and Spencer, 1995). In comparison, the mean $\mathrm{Pb}$ content of five other carbonate-dominated sediment samples on the Maunalua Bay reef flat was $6 \pm 1 \mu \mathrm{g} / \mathrm{g}$, lower than the pre-1927 value from the Ala Wai canal (Table 2). 

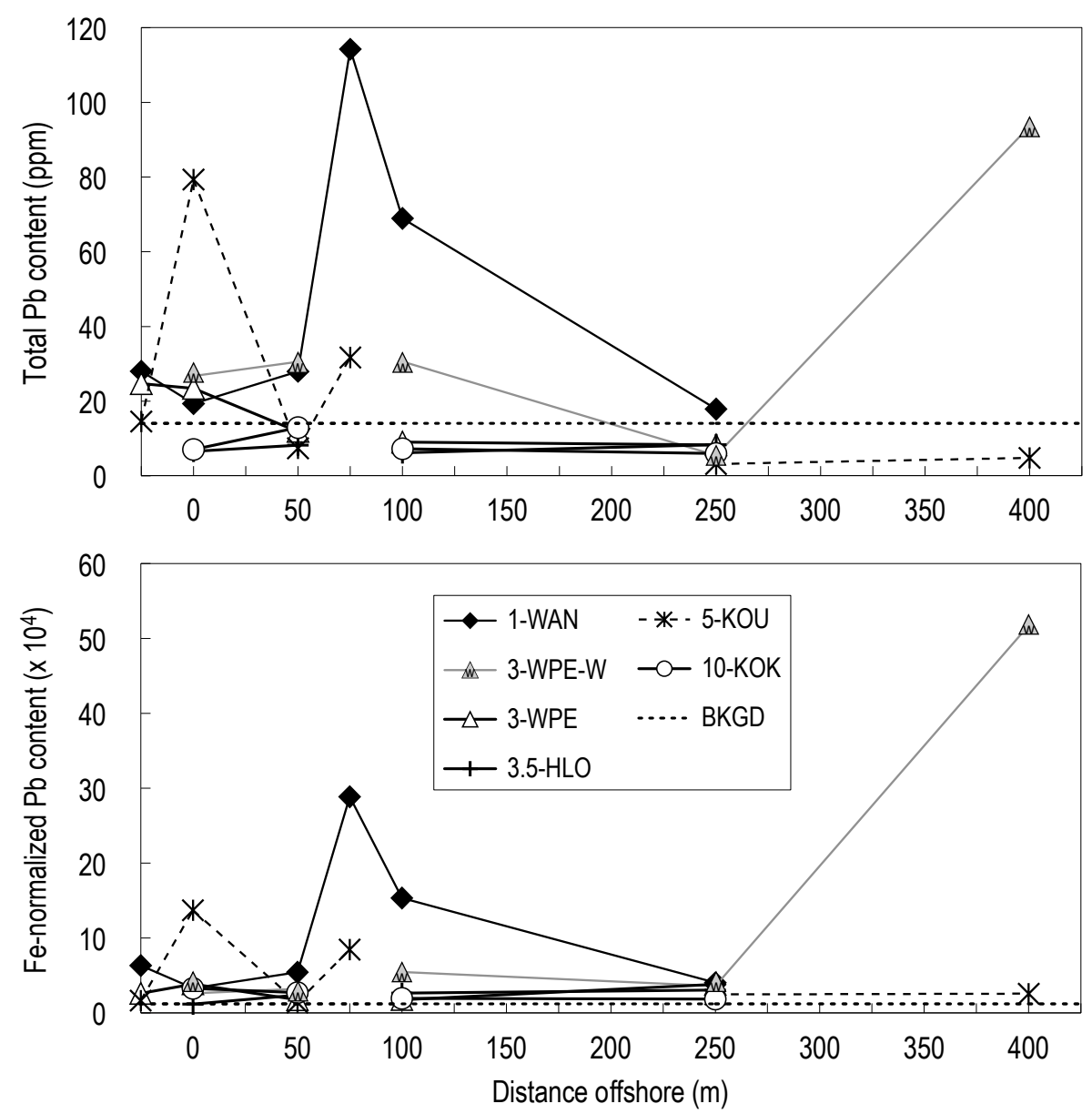

Figure 7. Plots of total lead $(\mathrm{Pb})$ and iron $(\mathrm{Fe})$-normalized $\mathrm{Pb}$ contents of estuarine and reef fine sediment with distance offshore. Estuarine values are shown to the left of $0 \mathrm{~m}$. Dotted lines show marine background levels (Table 2).

\section{Discussion}

High-standing and young islands in the tropics and subtropics can undergo high soil erosion rates and contribute large material fluxes to the coastal ocean (Hilton et al., 2008; Kao and Milliman, 2008; Lyons et al., 2002; Milliman and Syvitski, 1992). Such land-derived runoff of sediment, nutrients, carbon, and contaminants can have large impacts on global biogeochemical cycles (Milliman et al., 1999; Nittrouer et al., 1995; Sholkovitz et al., 1999) and marine and coastal ecosystems (Restrepo et al., 2006; Waycott et al., 2009). Many Hawaiian 
watersheds are small, steep, urbanized, and coupled to downstream ecologic communities, such as coral reefs and seagrasses, and socio-economic activities such as tourism and recreation, that rely on clean and clear water in coastal areas to flourish (GPA, 2006; Nurse et al., 2014). Sediment-geochemical signatures that identify areas contributing runoff could aid in the protection and restoration of coastal waters and ecosystems by identifying priority areas for management and remediation (Bartley et al., 2014).

\subsection{Watershed sources and nearshore dispersal of terrigenous sediment}

Geochemical signatures of tholeiitic and alkalic olivine basalt were able to distinguish fine sediment from basins in Koolau Range versus a contributing area on the west slope of Koko Head. Based on its geochemical signature, the majority of fine terrigenous sediment on the reef flat originated from basins in Koolau Range. Basin-specific sources could not be distinguished individually using the geochemical signatures explored here, except for the small sub-basin Wiliwilinui. Fine sediment from Wiliwilinui had a distinct $(\mathrm{La} / \mathrm{Yb})_{\mathrm{N}}$ and $\mathrm{Nb}_{\mathrm{Fe}}$ signature and its dispersal up to $2 \mathrm{~km}$ west and $150 \mathrm{~m}$ offshore of its source was consistent with the direction of trade-wind-driven sediment transport on south-facing fringing Hawaiian reefs (Ogston et al., 2004; Presto et al., 2006; Storlazzi et al., 2004). The size of Wiliwilinui was small compared to other basins, but the scale of the dispersal of its runoff signature on the reef flat was not. Therefore, runoff mitigation in this small basin could result in a relatively large improvement in land-based runoff impacts on the nearshore ecologic community.

The alkalic $(\mathrm{La} / \mathrm{Yb})_{\mathrm{N}}$ signature in fine sediment near the mouth of Niu Stream was another example of westward terrigenous sediment transport over several $\mathrm{km}$. The predominance of trade-wind-driven westward sediment transport has ecological implications for the reef 
community in Maunalua Bay in two ways. First, sediment and contaminants entering the bay will be entrained in westward flow and undergo repeated cycles of resuspension, deposition, and interaction with organisms (Ogston et al., 2004) before exiting the bay near Black Point (Presto et al., 2012; Storlazzi et al., 2010). Runoff plumes arising from winter storms, on the other hand, have short residence times in Maunalua Bay, exiting the reef rapidly in the offshore direction (Storlazzi et al., 2010; Wolanski et al., 2009). Second, runoff from the east part of the watershed near Hawaii Kai Marina, which consists of almost $20 \mathrm{~km}$ of shoreline with high-density residential and commercial development, had the highest levels of anthropogenic trace metals. Runoff from this region likely contains other compounds associated with urbanization (Brasher and Wolff, 2004) such as PAHs, pesticides, flame retardants, pharmaceuticals, and personal care products that are growing concerns in urban stormwater (Daughton and Ternes, 1999; Schwarzenbach et al., 2007) and groundwater (Barnes et al., 2008). Urban contaminants that are transported to the coastal ocean in surface runoff or groundwater can impact ecologic communities downstream of discharge sites.

There were few rainfall events during the 2008-2009 winter and spring preceding field sampling for this study, and flow in local streams was below normal, so runoff to the nearshore was also likely below normal. In this context, the relatively large amount of fine-grained terrigenous sediment on the Maunalua Bay reef flat, which averaged more than 25\%, was somewhat surprising, since the same component averaged less than $20 \%$ of the sediment transported off the reef flat during winter 2008-2009 (Storlazzi et al., 2010). From the absence of strong Kona storms during winter 2009-2010, it can be inferred that there were fewer large wave events that resuspended and transported sediment, resulting in greater storage of terrigenous material from previous flood events (Draut et al., 2009). Thus calm winter conditions appear to 
have contributed to the storage of land-derived sediment, and by association sediment-bound contaminants, on the Maunalua Bay reef flat.

The naturally high and variable contents of $\mathrm{Cr}$ and $\mathrm{Ni}$ in Hawaiian basalts are related to the minerals spinel and olivine, respectively (Frey et al., 1994; Haskins and Garcia, 2004; Jackson et al., 1999). The strong correlation of $\mathrm{Ni}$ and $\mathrm{Fe}$ in terrestrial fine sediment was indicative of the presence of olivine (De Carlo et al., 2005; Frey et al., 1994). When olivine is subaerially exposed it is susceptible to alteration; however, $\mathrm{Ni}$ was tightly coupled to $\mathrm{Fe}$ in fine sediment on the reef flat, indicating it was immobile (Marsaglia, 1993; Moberly et al., 1965) over the timescales of erosion and transport in the small drainages surrounding Maunalua Bay and thus not likely to be bioavailable (Sutherland, 2000). The high Cr content of upland sediment was also due to a volcanic source (De Carlo et al., 2005; Frey et al., 1994), and its biomodal distribution relative to $\mathrm{Fe}$ was indicative of two $\mathrm{Cr}$-bearing minerals. $\mathrm{Cr}$-spinel is ubiquitous in Hawaiian soil (Frey et al., 1994; Oze et al., 2004) and its composition would account for sediment with a high $\mathrm{Cr}$ to $\mathrm{Fe}$ ratio (Oze et al., 2004), whereas sediment with a lower $\mathrm{Cr}$ to $\mathrm{Fe}$ ratio could have contained Cr-bearing pyroxene (Nelson et al., 2013; Oze et al., 2004). Spinel and pyroxene are heavy minerals with densities approximately two times higher than terrigenous alumiosilicates and marine carbonates, so stronger hydraulic forcing is required for their suspension and transport than for similarly sized particles of lower density. As a result, heavy mineral transport can be decoupled from that of other particles in reef environments (Marsaglia, 1993; Moberly et al., 1965). Cr contents of about $1000 \mu \mathrm{g} / \mathrm{g}$ found in carbonate-dominated sediment $(<3 \%$ terrigenous) offshore of basins Wai' alae Nui and Portlock shows that high-Cr mineral grains remained on the Maunalua Bay reef flat after other terrigenous sediment was 
winnowed away. Therefore the distribution of $\mathrm{Cr}$ in fine-grained sediment on the reef flat is not representative of overall fine-sediment transport and deposition patterns.

\subsection{Anthropogenic trace metals in the Maunalua Bay system}

The elevated $\mathrm{Cu}$ content of soil and sediment in the Maunalua Bay watershed, although affected by anthropogenic activities (De Carlo et al., 2004), is due primarily to a large geologic component (De Carlo et al., 2005), almost $60 \%$ of the total (Sutherland and Tolosa, 2000), which is not biologically available. The occurrence of some of the highest soil $\mathrm{Cu}$ contents in forested parkland where motor vehicle operation is minimal underscores the geologic control of this trace metal. The three-fold variation of terrestrial soil and sediment $\mathrm{Cu}_{\mathrm{Fe}}$ contents reflects the natural variability of $\mathrm{Cu}$ in tholeiitic and alkalic olivine basalt lavas.

A stronger anthropogenic influence was found for fine sediment $\mathrm{Cd}$ and $\mathrm{Zn}$ contents in the Maunalua watershed, as evidenced by the occurrence of maximum values near the urban center in the east part of the watershed and a six-fold or higher enrichment over geologic background levels. This is consistent with previous studies showing that $\mathrm{Cd}$ and $\mathrm{Zn}$ in Hawaiian soils are anthropogenically influenced (e.g., De Carlo and Spencer, 1995; De Carlo et al., 2005; Sutherland, 2000). Elevated fine-sediment contents of $\mathrm{Cd}$ and $\mathrm{Zn}$ in the estuarine reaches of streams and near storm drain outfalls indicate that these trace metals were entrained in runoff

from the urbanized watershed and deposited at the land-sea interface, as is typical in estuaries ( $\mathrm{Li}$ et al., 1984; Turekian, 1977). Although nearshore fine sediment with anthropogenic $\mathrm{Cd}$ and $\mathrm{Zn}$ was confined to the inner $75 \mathrm{~m}$ of the reef flat under the dry conditions preceding this study, sediment and contaminant runoff and its dispersal could be higher in wetter years. Furthermore, because motor vehicle traffic is the primary urban source of Cd and Zn (De Carlo et al., 2005; 
Sutherland, 2000), loading of these metals to the coastal ocean is expected to increase as population increases in the state of Hawaii (HOP, 2013). Increasing runoff of sediment and urban contaminants is a global concern as coastal regions become more populated and urbanized (Newton et al., 2012).

$\mathrm{Pb}$ contents of urban soils on Oahu have been decreasing since the phase-out of leaded gasoline in the 1980s (De Carlo and Anthony, 2002). Fine-grained sediment with high $\mathrm{Pb}_{\mathrm{Fe}}$ values relative to background levels indicate that legacy $\mathrm{Pb}$-contaminated soil and sediment are still present in urban watersheds of southeast Oahu, though the $\mathrm{Pb}$ levels reported here are lower than during the USGS National Water Quality Assessment a decade earlier. The Pb content of nearshore carbonate sediment can reflect marine as well as anthropogenic processes. Carbonate has a strong affinity for $\mathrm{Pb}$ in seawater (Talbot and Chegwidden, 1983), and $\mathrm{Pb}$ enrichment of marine carbonate can occur by passive adsorption (Sturesson, 1976), also called scavenging, particularly when sediment is resuspended, which likely occurs almost daily on the Maunalua Bay reef flat for more than 6 months of the year when trade winds prevail (Presto et al., 2006). Scavenging can account for nearshore $\mathrm{Pb}$ contents of fine-grained carbonate sediment that were two to three times higher than the marine background, values that were comparable to $\mathrm{Pb}$ levels in calcareous sediment in other shallow water environments in Australia (Esslemont, 2000; Talbot and Chegwidden, 1983) and Central America (Guzman and Jimenez, 1992). Lead enrichments in nearshore fine sediment in excess of $\mathrm{Pb}$-scavenging were attributed to anthropogenic legacy $\mathrm{Pb}$ from the dispersal of land-based runoff across the Maunalua Bay reef flat. Legacy $\mathrm{Pb}$ was found along three of five transects on the reef flat; however, it did not occur at levels where biological impacts would be expected. 


\subsection{Implications}

Urbanization and development of coastal zones are increasing worldwide, and concomitant increases in material fluxes from land to sea could irreparably disrupt coastal processes and ecosystems if corrective measures are not undertaken (Hughes et al., 2010; Jackson, 2008; Steffen et al., 2011). Sediment geochemical signatures represent one means to improve the effectiveness of runoff reduction and control efforts by identifying runoffcontributing areas, information that can inform watershed management practices (Bartley et al., 2014). In the coastal zone, geochemical signatures can provide insights about land-based sediment and contaminant transport in relation to ecological communities, information that is important for restoration efforts.

\section{Conclusions}

The health and resilience of coral reefs has been shown to improve when land-based sediment and contaminant runoff is reduced. Insights about runoff sources gained from sediment geochemical signatures would make runoff management more effective by targeting priority contributing areas. A sediment geochemical signature based on $(\mathrm{La} / \mathrm{Yb})_{\mathrm{N}}$ showed a clear distinction between the two main rock types, tholeiitic and alkalic olivine basalt, in the contributing area of a coral-reef fringed embayment in southeast Oahu, Hawaii. Asian dust was only a minor component of soil and sediment in southeast Oahu. One of five tholeiitic basins in the overall contributing area could be individually distinguished using $(\mathrm{La} / \mathrm{Yb})_{\mathrm{N}}$ and $\mathrm{Nb}_{\mathrm{Fe}}$. Fine sediment from this small sub-basin was dispersed over a large section of the reef flat, illustrating how hydrodynamic sediment transport can increase the scale of runoff impacts in coastal areas, and how geochemical signatures can identify potential target areas for runoff control. 
Anthropogenic metals $\mathrm{Cd}, \mathrm{Pb}$, and $\mathrm{Zn}$ were associated with fine sediment from the most heavily urbanized portion of the watershed, and were entrained in runoff to the reef flat. Other trace metals $\mathrm{Cr}, \mathrm{Cu}$, and $\mathrm{Ni}$ were associated with volcanic minerals in Hawaiian soil and sediment, so were unlikely to pose ecological risks. Sediment-source attribution with geochemical signatures can be a valuable tool for the implementation of effective runoff control measures, a strategy that has become critical for the protection and restoration of coastal ecosystems as urbanization and exploitation of coastal areas increase worldwide.

\section{Acknowledgments}

This work was funded by and carried out as part of the USGS Pacific Coral Reef Project, an effort in the U.S. and its trust territories to better understand the effect of geologic processes on coral reef systems. Funding was provided by the USGS Coastal and Marine Geology Program. The authors thank Cheryl Hapke (USGS) for laying the groundwork for the field study; Alyssa Miller and Jolie Wagner, on staff at the time of this study with Malama Maunalua, for guidance and logistical support during upland and marina sediment collection; Leticia Hallas for assistance processing samples; and Rob Franks of the University of California at Santa Cruz for assistance with ICP-MS analyses. John Crusius (USGS) and anonymous reviewers provided excellent suggestions than improved the manuscript. Any use of trade, product, or firm names is for descriptive purposes only and does not imply endorsement by the U.S. Government.

\section{References}

Alloway, B.J., 1995. Heavy metals in soils. Blackie Academic \& Professional, London.

Araújo, M.F., Jouanneau, J.-M., Valério, P., Barbosa, T., Gouveia, A., Weber, O., Oliveira, A., Rodrigues, A., Dias, J.M.A., 2002. Geochemical tracers of northern Portuguese estuarine sediments on the shelf. Prog. Oceanog. 52, 277-297. doi: 10.1016/j.csr.2004.02.010 
Barnes, K.K., Kolpin, D.W., Furlong, E.t., Zaugg, S.D., Meyer, M.T., Barber, L.B., 2008. A national reconaissance of pharmaceuticals and other organic wastewater compounds in the United States - I) Groundwater. Sci. Total Environ. 402, 192-200. doi: 10.1016/j.scitotenv.2008.04.028

Bartley, R., Bainbridge, Z.T., Lewis, S.E., Kroon, F.J., Wilkinson, S.N., Brodie, J.E., Silburn, D.M., 2014. Relating sediment impacts on coral reefs to watershed sources, processes, and management: a review. Sci. Total Environ. 468-469, 1138-1153. doi: 10.1016/j.scitotenv.2013.09.030

Brasher, A.M.D., Wolff, R.H., 2004. Relations between land use and organochlorine pesticides, PCBs, and semi-volatile organic compounds in streambed sediment and fish on the Island of Oahu, Hawaii. Archive of Environment Contamination and Toxicology 46, 385-398. doi: 10.1007/s00244-003-30194

Brunskill, G.J., Woolfe, K.J., Zagorskis, I., 1995. Distribution of riverine sediment chemistry on the shelf, slope and rise of the Gulf of Papua. Geo-Mar. Lett. 15, 160-162. doi: 10.1007/BF01204458

Clague, D.A., Frey, F.A., 1982. Petrology and trace element geochemistry of the Honolulu Volcanics, Oahu: implications for the oceanic mantle below Hawaii. J. Petrol. 23, 447-504. doi: 10.1093/petrology/23.3.447

Coles, S.L., DeFelice, R.C., Eldredge, L.G., 2002. Nonindigenous marine species at Waikiki and Hawaii Kai, Oahu, Hawaii. Bishop Musuem Technical Report No. 25, Honolulu, Hawaii. 255 p.

Collins, A.L., Walling, D.E., 2002. Selecting fingerprint properties for discriminating potential suspended sediment sources in river basins. J. Hydrol. 261, 218-244. doi: 10.1016/S0022-1694(02)00011-2

Daughton, C.G., Ternes, T.A., 1999. Pharmaceuticals and personal care products in the environment: agents of subtle change? Environ. Health Perspect. 107, Supp. 6, 907-938. doi: http://www.justor.org/stable/3434573

De Carlo, E.H., Anthony, S.S., 2002. Spatial and temporal variability of trace element concentrations in an urban subtropical watershed, Honolulu, Hawaii. Appl. Geochem. 17, 475-492. doi: 10.1016/S0883-2927(01)00114-7

De Carlo, E.H., Beltran, V.L., Tomlinson, M.S., 2004. Composition of water and suspended sediment in streams of urbanized subtropical watersheds in Hawaii. Appl. Geochem. 19, 1011-1037. doi: 10.1016/0025-326X(95)98338-W

De Carlo, E.H., Spencer, K.J., 1995. Sedimentary records of anthropogenic inputs of heavy metals to the Ala Wai a small man-made estuary in Honolulu, Hawaii. Pac. Sci. 49, 471-491.

De Carlo, E.H., Tomlinson, M.S., Anthony, S.S., 2005. Trace elements in streambed sediments of small subtropical streams on O'ahu, Hawai'i: Results from the USGS NAWQA program. Appl. Geochem. 20, 2157-2188. doi: 10.1016/0025-326X(95)98338-W

Done, T., 1995. Remediation of degraded coral reefs: the need for a broad focus. Mar. Pollut. Bull. 30, 686-688. doi: 10.1016/0025-326X(95)98338-W

Draut, A.E., Bothner, M.H., Field, M.E., Reynolds, R.L., Cochran, S.A., Logan, J.B., Storlazzi, C.D., Berg, C.J., 2009. Supply and dispersal of flood sediment from a steep, tropical watershed: Hanalei Bay, Kaua'i, Hawai'i, USA. Geo. Soc. Am. Bull. 121, 574-585. doi: 10.1130/B26367.1

Dymond, J., Biscaye, P.E., Rex, R.W., 1974. Eolian origin of mica in Hawaiian soils. Geo. Soc. Am. Bull. 85, 37-40. doi: 10.1130/0016-7606(1974)85<37:EOOMIH>2.0.CO;2

Esslemont, G., 2000. Heavy metals in seawater, marine sediments and corals from the Townsville section, Great Barrier Reef Marine Park, Queensland. Mar. Chem. 71, 215-231. doi: 10.1016/S03044203(00)00050-5 
Fabricius, K.E., 2005. Effects of terrestrial runoff on the ecology of corals and coral reefs: review and synthesis. Mar. Pollut. Bull. 50, 125-146. doi: 10.1016/j.marpolbul.2004.11.028

Ferrat, M., Weiss, D.J., Strekopytov, S., Dong, S., Chen, H., Najorka, J., Sun, Y., Gupta, S., Tada, R., Sinha, R., 2011. Improved provenance tracing of Asian dust sources using rare earth elements and selected trace elements for paleomonsoon studies on the eastern Tibetian Plateau. Geochim. Cosmochim. Acta 75, 6374-6399. doi: 10.1016/j.gca.2011.08.025

Frey, F.A., Garcia, M.O., Roden, M.F., 1994. Geochemical characteristics of Koolau Volcano: implications of intershield geochemical differences among Hawaiian volcanoes. Geochim. Cosmochim. Acta 58, 1441-1462. doi: 10.1016/0016-7037(94)90548-7

Frissell, C.A., Liss, W.J., Warren, C.E., Hurley, M.D., 1986. A heirarchial framework for stream habitat classification: viewing streams in a watershed context. Environ. Manage. 10, 199-214. doi: 10.1007/BF01867358

Giambelluca, T.W., Chen, Q., Frazier, A.G., Price, J.P., Chen, Y.-L., Chu, P.-S., Eischeid, J.K., Delparte, D.M., 2013. Online rainfall atlas of Hawai'i. B. Am. Meteorol. Soc. 94, 313-316. doi: 10.1175/BAMS-D-11-00228.1

GPA, 2006. Protecting coastal and marine environments from impacts of land-based activities: a guide for national action. United Nations Environment Programme (UNEP) Global Programme of Action for the Protection of the Marine Environment from Land-Based Activities (GPA), The Hague, p. 107.

Gramlich, J.W., Lewis, V.A., Naughton, J.J., 1971. Potassium-argon dating of Holocene basalts of the Honolulu Volcanic Series. Geo. Soc. Am. Bull. 82, 1,399-391,404. doi: 10.1130/00167606(1971)82[1399:PDOHBO]2.0.CO;2

Guzman, H.M., Jimenez, C.E., 1992. Contamination of coral reefs by heavy metals along the Caribbean coast of Central America. Mar. Pollut. Bull. 24, 554-561. doi: 10.1016/0025-326X(92)90708-E

Haskins, E.H., Garcia, M.O., 2004. Scientific drilling reveals geochemical heterogeneity within the Ko'olau shield, Hawai'i. Contrib. Mineral. Petrol. 147, 162-188. doi: 10.1007/s00410-003-0546-y

Hilton, R.G., Galy, A., Hovius, N., Chen, M.-C., Horng, M.-J., Chen, H., 2008. Tropical-cyclone-driven erosion of the terrestrial biosphere from mountains. Nat. Geosci. 1, 759-762. doi: 10.1038/ngeo333

HOP, 2013. Hawaii Ocean Resources Management Plan. Hawaii Office of Planning, Coastal Zone Management Program, Honolulu, p. 152.

Huang, S., Frey, F.A., 2005. Recycled oceanic crust in the Hawaiian Plume: evidence from temporal geochemical variations within the Koolau Shield. Contrib. Mineral. Petrol. 149, 556-575. doi: doi: 10.1007/s00410-005-0664-9

Hughes, T.P., Graham, N.A.J., Jackson, J.B.C., Mumby, P.J., Steneck, R.S., 2010. Rising to the challenge of sustaining coral reef resilience. Trends in Ecology and Evolution 25, 633-642. doi: 10.1016/j.tree.2010.07.011

Hunter, C.L., Evans, C.W., 1995. Coral reefs in Kaneohe Bay, Hawaii: two centuries of western influence and two decades of data. B. Mar. Sci. 57, 501-515.

Jackson, J.B.C., 2008. Ecological extinction and evolution in the brave new ocean. P. Natl. Acad. Sci. U.S.A. 105, 11458-11465. doi: 10.1073/pnas.0802812105

Jackson, J.B.C., Kirby, M.X., Berger, W.H., Bjorndal, K.A., Botsford, L.W., Bourque, B.J., Bradbury, R.H., Cooke, R., Erlandson, J., Estes, J.A., Hughes, T.P., Kidwell, S., Lange, C.B., Lenihan, H.S., Pandolfi, J.M., Peterson, C.H., Steneck, R.S., Tegner, M.J., Warner, R.R., 2001. Historical overfishing and the recent collapse of coastal ecosystems. Science 293, 629-638. doi: $10.1126 /$ science. 1059199 
Jackson, M.C., Frey, F.A., Garcia, M.O., Wilmoth, R.A., 1999. Geology and geochemistry of basaltic lava flows and dikes from the Trans-Koolau tunnel, Oahu, Hawaii. B. Volcanol. 60, 381-401.

Jackson, M.L., Levelt, T.W.M., Syers, J.K., Rex, R.W., Clayton, R.N., Sherman, G.D., Uehara, G., 1971. Geomorphological relationships of tropospherically derived quartz in the soils of the Hawaiian Islands. Soil Sci. Soc. Am. J. 35, 515-525. doi: 10.2136/sssaj1971.03615995003500040015x

Kao, S.J., Milliman, J.D., 2008. Water and sediment discharges from small mountainous rivers, Taiwan: the roles of lithology, episodic events, and human activities. J. Geol. 116, 431-448. doi: $10.1086 / 590921$

Knowlton, N., 2001. The future of coral reefs. P. Natl. Acad. Sci. U.S.A. 98, 5419-5425. doi: 10.1073/onas.091092998

Kurtz, A.C., Derry, L.A., Chadwick, O.A., 2001. Accretion of Asian dust to Hawaiian soils: isotopic, elemental, and mineral mass balance. Geochim. Cosmochim. Acta 65, 1971-1983. doi: 10.1016/S0016-7037(01)00575-0

Kurtz, A.C., Derry, L.A., Chadwick, O.A., Alfano, M.J., 2000. Refractory element mobility in volcanic soils. Geology 28, 683-686. doi: 10.1130/0091-7613(2000)28<683:REMIVS>2.0.CO;2

Li, Y.-H., Burkhardt, L., Teraoka, H., 1984. Desorption and coagulation of trace elements during estuarine mixing. Geochim. Cosmochim. Acta 48, 1879-1884. doi: 10.1016/0016-7037(84)90371-5

Long, E.R., MacDonald, D.D., Smith, S.L., Calder, F.D., 1995. Incidence of adverse biological effects within ranges of chemical concentrations in marine and estuarine sediments. Environ. Manage. 19, 81-97. doi: 10.1007/BF02472006

Lotze, H.K., Lenihan, H.S., Bourque, B.J., Bradbury, R.H., Cooke, R.G., Kay, M.C., Kidwell, S.M., Kirby, M.X., Peterson, C.H., Jackson, J.B.C., 2006. Depletion, degradation, and recovery potential of estuaries and coastal seas. Science 312, 1806-1808. doi: 10.1126/science.1128035

Lyons, W.B., Nezat, C.A., Carey, A.E., Hicks, D.M., 2002. Organic carbon fluxes to the ocean from highstanding islands. Geology 30, 443-446. doi: 10.1130/0091-7613(2002)030<0443:OCFTTO >2.0.CO;2

MacDonald, D.D., Ingersoll, C.G., Berger, T.A., 2000. Development and evaluation of consensus-based sediment quality guidelines for freshwater ecosystems. Arch. Environ. Contam. Toxicol. 39, 20-31. doi: $10.1007 / \mathrm{s} 002440010075$

Marsaglia, K.M., 1993. Basaltic island sand provenance, in: Johnsson, M.J., Basu, A. (Eds.), Processes Controlling the Composition of Clastic Sediments. Geological Society of America Special Papers 284, Boulder, CO, pp. 41-65.

McLennan, S.M., 1989. Rare earth elements in sedimentary rocks: influence of provenance and sedimentary processes, in: Lipin, B.R., McKay, G.A. (Eds.), Rare earth elements. Reviews in Mineralogy, Washington D.C., pp. 169-200.

McLennan, S.M., Hemming, S., McDaniel, D.K., Hanson, G.N., 1993. Geochemical approaches to sedimentation, provenance, and tectonics, in: Johnsson, M.J., Basu, A. (Eds.), Processes controlling the composition of clastic sediment. Geological Society of America Special Paper 284, Boulder, pp. $21-40$.

Mee, L., 2012. Between the devil and the deep blue sea: the coastal zone in an era of globalization. Estuarine, Coastal and Shelf Science 96, 1-8. doi: doi: 10.1016/j.ecss.2010.02.013

Milliman, J.D., Farnsworth, K.L., Albertin, C.S., 1999. Flux and fate of fluvial sediments leaving large islands in the East Indies. J. Sea Res. 41, 97-107. doi: 10.1016/S1385-1101(98)00040-9 
Milliman, J.D., Syvitski, J.P.M., 1992. Geomorphic/tectonic control of sediment discharge to the ocean: the importance of small mountainous rivers J. Geol. 100, 525-544. doi: http://www.jstor.org/stable/30068527

Moberly, R., Baver, L.D., Morrison, A., 1965. Source and variation of Hawaiian littoral sand. J. Sediment. Petrol. 35, 589-598.

Nakai, S., Halliday, A.N., Rea, D.K., 1993. Provenance of dust in the Pacific Ocean. Earth. Planet. Sci. Lett. 119, 143-157. doi: 10.1016/0012-821X(93)90012-X

Nelson, S.T., Tingey, D.G., Selck, B., 2013. The denudation of ocean islands by ground and surface waters: the effects of climate, soil thickness, and water contact times on Oahu, Hawaii. Geochim. Cosmochim. Acta 103, 276-294. doi: 10.1016/j.gca.2012.09.046

Newton, A., Carruthers, T.J.B., Icely, J., 2012. The coastal syndromes and hotspots on the coast. Estuar. Coast. Shelf. Sci. 96, 39-47. doi: 10.1016/j.ecss.2011.07.012

Nittrouer, C.A., Brunskill, G.J., Figueiredo, A.G., 1995. Importance of tropical coastal environments. Geo-Mar. Lett. 15, 121-126. doi: 10.1007/BF01204452

Nurse, L.A., McLean, R.F., Agard, J., Briguglio, L.P., Duvat-Magnan, V., Pelesikoti, N., Tompkins, E., Webb, A., 2014. Small islands, in: Barros, V.R., Field, C.B., Dokken, D.J., Mastrandrea, M.D., Mach, K.J., Bilir, T.E., Chatterjee, M., Ebi, K.L., Estrada, Y.O., Genova, R.C., Girma, B., Kissel, E.S., Levy, A.N., MacCracken, S., Mastrandrea, P.R., White, L.L. (Eds.), Climate change 2014: Impacts, adaptation, and vulnerability. Part B: Regional aspects. Contribution of Working Group II to the Fifth Assessment Report of the Intergovernmental Panel on Climate Change. Cambridge University Press, Cambridge, UK, pp. 1613-1654.

Ogston, A.S., Storlazzi, C.D., Field, M.E., Presto, M.K., 2004. Sediment resuspension and transport patterns on a fringing reef flat, Molokai, Hawaii. Coral Reefs 23, 559-569. doi: 10.1007/s00338-0040415-9

Oki, D.S., Brasher, A.M.D., 2003. Environmental setting and the effects of natural and human-related factors on water quality and aquatic biota, Oahu, Hawaii. U.S. Geological Survey Water-Resources Investigations Report 03-4156, p. 98.

Oze, C., Fendorf, S., Bird, D.K., Coleman, R.G., 2004. Chromium geochemistry of serpentine soils. Int. Geol. Rev. 46, 97-126. doi: 10.2747/0020-6814.46.2.97

Pandolfi, J.M., Jackson, J.B.C., Baron, N., Bradbury, R.H., Guzman, H.M., Hughes, T.P., Kappel, C.V., Micheli, F., Ogden, J.C., Possingham, H.P., Sala, E., 2005. Are U.S. coral reefs on the slippery slope to slime? Science 307, 1725-1726. doi: 10.1126/science.1104258

Porder, S., Hilley, G.E., Chadwick, O.A., 2007. Chemical weathering, mass loss, and dust inputs across a climate by time matrix in the Hawaiian Islands. Earth. Planet. Sci. Lett. 258, 414-427. doi: 10.1016/j.eps1.2007.03.047

Prego, R., Caetano, M., Bernárdez, P., Brito, P., Ospina-Alvarez, N., Vale, C., 2012. Rare earth elements in coastal sediment of the northern Galician shelf: influence of geologic features. Cont. Shelf Res. 35, 75-85. doi: 10.1016/j.csr.2011.12.010

Prego, R., Caetano, M., Vale, C., Marmolejo-RodrÍguez, J., 2009. Rare earth elements in sediments of the Vigo Ria, NW Iberian Peninsula. Cont. Shelf Res. 29, 896-902. doi: 10.1016/j.csr.2009.01.009

Presley, T.K., Jamison, T.J., 2010. Rainfall, discharge, and water-quality data during stormwater monitoring, H-1 storm drain, Oahu, Hawaii, July 1, 2009 to June 30, 2010. U.S. Geological Survey Open-File Report 2010-1161, Reston, Virginia, p. 30. 
Presto, M.K., Ogston, A.S., Storlazzi, C.D., Field, M.E., 2006. Temporal and spatial variability in the flow and dispersal of suspended-sediment on a fringing reef flat, Molokai, Hawaii. Estuar. Coast. Shelf. Sci. 67, 67-81. doi: 10.1016/j.ecss.2005.10.015

Presto, M.K., Storlazzi, C.D., Logan, J.B., Reiss, T.E., Rosenberger, K.J., 2012. Coastal circulation and potential coral larval dispersal in Maunalua Bay, Oahu, Hawaii. U.S. Geological Survey Open-File Report 2012-1040, p. 67.

Restrepo, J.D., Park, E., Aquino, S., Latrubesse, E.M., 2016. Coral reefs chronically exposed to river sediment plumes in the southwest Caribbean: Rosario Islands, Colomiba. Sci. Total Environ. 553, 316-329. doi: 10.1016/j.scitotenv.2016.02.140

Restrepo, J.D., Zapata, P., Diaz, J.M., Garzon-Ferreira, J., Garcia, C.B., 2006. Fluvial fluxes into the Caribbean Sea and their impact on coastal ecosystems: the Magdalena River, Colombia. Global Planet. Change 50, 33-49. doi: 10.1016/j.gloplacha.2005.09.002

Rex, R.W., Syers, J.K., Jackson, M.L., Clayton, R.N., 1969. Eolian origin of quartz in soils of Hawaiian Islands and in Pacific pelagic sediments. Science 163, 277-279. doi: 10.1126/science.163.3864.277

Richmond, R.H., Rongo, T., Golbuu, Y., Victor, S., Idechong, N., Davis, G., Kosta, W., Neth, L., Hamnett, M., Wolanski, E., 2007. Watersheds and coral reefs: conservation science, policy, and implementation. BioScience 57, 598-607. doi: 10.1641/B570710

Roden, M.F., Frey, F.A., Clague, D.A., 1984. Geochemistry of tholeiitic and alkalic lavas from the Koolau Range, Oahu, Hawaii: implications for Hawaiian volcanism. Earth. Planet. Sci. Lett. 69, 141 158. doi: $10.1016 / 0012-821 X(84) 90079-7$

Rogers, C.S., 1990. Responses of coral reefs and reef organisms to sedimentation. Mar. Ecol-Prog. Ser. 62, 185-202. doi: 10.3354/meps062185

Roussiez, V., Aubert, D., Heussner, S., 2013. Continental sources of particles escaping the Gulf of Lion evidenced by rare earth elements: Floods vs. normal conditions. Mar. Chem. 153, 31-38. doi: 10.1016/j.marchem.2013.04.010

Schwarzenbach, R.P., Escher, B.I., Fenner, K., Hofstetter, T.B., Johnson, C.A., von Gunten, U., Wehrli, B., 2007. The challenge of micropollutants in aquatic systems. Science 313, 1072-1077. doi: $10.1126 /$ science. 1127291

Sholkovitz, E.R., Elderfield, H., Szymcak, R., Casey, K., 1999. Island weathering: river sources of rare earth elements tot he Western Pacific Ocean. Mar. Chem. 68, 39-57. doi: 10.1016/S03044203(99)00064-X

Short, F.T., Wyllie-Echeverria, S., 1996. Natural and human-induced disturbance of seagrasses. Environ. Conserv. 23, 17-27. doi: 10.1017/S0376892900038212

Smith, J., Douglas, G.B., Radke, L.C., Palmer, M., Brooke, B.P., 2008. Fitzroy River Basin, Queensland, Australia. III. Identification of sediment sources in the coastal zone. Environ. Chem. 5, 231-242. doi: 10.1071/EN07094

Stearns, H.T., Vaksvik, K.N., 1935. Geology and ground-water resources of the island of Oahu, Hawaii. Hawaii Division of Hydrography, Bulletin 1, Honolulu, p. 479.

Steffen, W., Persson, A., Deutsch, L., Zalasiewicz, J., Williams, M., Richardson, K., Crumley, C., Crutzen, P., Folke, C., Gordon, L., Molina, M., Ramanathan, V., Rockström, J., Scheffer, M., Schellnhuber, H.J., Svedin, U., 2011. The Anthropocene: from global change to planetary stewardship. Ambio 40, 739-761. doi: 10.1007/s13280-011-0185-x 
Storlazzi, C.D., Ogston, A.S., Bothner, M.H., Field, M.E., Presto, M.K., 2004. Wave- and tidally-driven flow and sediment flux across a fringing coral reef: southern Molokai, Hawaii. Cont. Shelf Res. 24, 1397-1419. doi: 10.1016/j.csr.2004.02.010

Storlazzi, C.D., Presto, M.K., Logan, J.B., Field, M.E., 2010. Coastal circulation and sediment dynamics in Maunalua Bay, Oahu, Hawaii. U.S. Geological Survey Open-File Report 2010-1217, p. 59.

Sturesson, U., 1976. Lead enrichment in shells of Mytilus edulis. Ambio 5, 253-256. doi:

Sutherland, R.A., 2000. Bed sediment-associated trace metals in an urban stream, Oahu, Hawaii. Environ. Geol. 39, 611-627. doi: 10.1007/s002540050473

Sutherland, R.A., Tolosa, C.A., 2000. Multi-element analysis of road-deposited sediment in an urban drainage basin, Honolulu, Hawaii. Environ. Pollut. 110, 483-495. doi: 10.1016/S02697491(99)00311-5

Talbot, V., Chegwidden, A., 1983. Heavy metals in the sediments of Cockburn Sound, Western Australia, and its surrounding areas. Environ. Pollut. B 5, 187-205. doi: 10.1016/0143-148X(83)90003-4

Tomlinson, M.S., De Carlo, E.H., 2003. The need for high resolution time series data to characterize Hawaiian streams. J. Am. Water Resour. As. 39, 113-123. doi: 10.1111/j.1752-1688.2003.tb01565.x

Turekian, K.K., 1977. The fate of metals in the coeans. Geochim. Cosmochim. Acta 41, 1139-1144. doi: 10.1016/0016-7037(77)90109-0

USEPA, 1996. Method 3052: Microwave assisted acid digestion of siliceous and organically based matrices, part of the test methods for evaluating solid waste, physical/chemical methods. U.S. Environmental Protection Agency, https://www.epa.gov/hw-sw846/sw-846-test-method-3052microwave-assisted-acid-digestion-siliceous-and-organically-based, p. 20.

Vitousek, P.M., Chadwick, O.A., Crews, T.E., Fownes, J.H., Hendricks, D.M., Herbert, D., 1997. Soil and ecosystem development across the Hawaiian Islands. GSA Today 7, 1-8.

Waycott, M., Duarte, C.M., Carruthers, T.J.B., Orth, R.J., Dennison, W.C., Olyarnik, S., Calladine, A., Fourqurean, J.W., Heck, K.L., Jr., Hughes, A.R., Kendrick, G.A., Kenworthy, W.J., Short, F.T., Williams, S.L., 2009. Accelerating loss of seagrasses across the globe threatens coastal ecosystems. P. Natl. Acad. Sci. U.S.A. 106, 12377-12381. doi: 10.1073/pnas.0905620106

Wentworth, C.K., Winchell, H., 1947. Koolau basalt series, Oahu, Hawaii. Geo. Soc. Am. Bull. 58, 4978. doi: 10.1130/0016-7606(1947)58[49:KBSOH]2.0.CO;2

Winchell, H., 1947. Honolulu series, Oahu, Hawaii. Geo. Soc. Am. Bull. 58, 1-48. doi: 10.1130/00167606(1947)58[1:HSOH]2.0.CO;2

Windom, H.L., Schropp, S.J., Calder, F.D., Ryan, J.D., Smith, R.G., Burnery, L.C., Lewis, F.G., Rawlinson, C.H., 1989. Natural trace metal concentrations in estuarine and coastal marine sediments of the southeastern United States. Environ. Sci. Technol. 23, 314-320. doi: 10.1021/es00180a008

Wolanski, E., Martinez, J.A., Richmond, R.H., 2009. Quantifying the impact of watershed urbanization on a coral reef: Maunalua Bay, Hawaii. Estuar. Coast. Shelf. Sci. 84, 259-268. doi: $10.1021 / \mathrm{es} 00180 \mathrm{a} 008$ 


\section{FIGURE CAPTIONS}

Figure 1. Shaded relief map of southeast Oahu showing Maunalua Bay (white line marks the shoreline) and its watershed (dashed line). Drainage basins are identified with numbers and abbreviations described in Section 3.1. Streams in basins 1-5 are shown by name. The sub-basin 3-WPE-W (Wiliwilinui) is denoted by a ' $\mathrm{w}$ ' inside a gray triangle. Black triangles show USGS gaging stations (GS) on Wailupe and Waiakeakua Streams. 'terr', terrestrial; 'ns', nearshore. Black lines on the reef flat show reef transects. The $5 \mathrm{~m}$ isobath is shown for reference. Inset shows the location of Maunalua Bay in the Main Hawaiian Islands.

Figure 2. Time series plots of wind direction (top) and wind speed (middle) at NOS Meteorological Station 1612340 in Honolulu. Bottom panel shows stream discharge and total suspended sediment concentration (TSS) in Wailupe Stream at USGS gaging station 16247550 from 1 October 2009 through 30 June 2010.

Figure 3. Comparisons of enrichment factors $(\mathrm{EF})$ of Fe-normalized immobile and relatively immobile elements in the fine fraction of terrestrial soil and sediment derived from tholeiitic (THO) and alkalic olivine basalt (AOB) relative to their coefficients of variation (CV). Circles show groupings for THO and AOB corresponding to the labeled element. Dashed line shows $\mathrm{EF}=2$. Symbols below the line are for $\mathrm{Sc}_{\mathrm{Fe}}, \mathrm{Cr}_{\mathrm{Fe}}, \mathrm{Co}_{\mathrm{Fe}}, \mathrm{Ni}_{\mathrm{Fe}}$, and $\mathrm{Zr}_{\mathrm{Fe}}$.

Figure 4. Plot of fine-sediment lanthanum $\left(\mathrm{La}_{\mathrm{N}}\right)$ relative to ytterium $\left(\mathrm{Yb}_{\mathrm{N}}\right)$ contents in terrestrial (large symbols) and marine environments (small symbols). The average composition and 
standard deviation (error bars) of tholeiitic basalt (THO) are shown for reference, data from Frey et al. (1994). The dashed line shows the least-squares regression through HLO $(r=0.9980, \mathrm{n}=4)$ extrapolated from $\mathrm{Yb}_{\mathrm{N}}=0.5$ to low $\mathrm{Yb}_{\mathrm{N}}$ values. The compositions of alkalic olivine basalts (AOB) are shown for reference, data from Clague and Frey (1982) with a least-squares regression line ( $r=0.9949, \mathrm{n}=3$, dotted line). The star shows the composition of Asian dust in North Pacific pelagic sediment near Hawaii (Nakai et al., 1993).

Figure 5. Box and whisker plots of Fe-normalized barium (Ba), niobium (Nb), and thorium (Th) contents of fine-sediment from five tholeiitic basins (1-5) and Hawaii Loa Ridge (3.5). The height of the box shows the interquartile range, the whiskers show the maximum and minimum values, and the line crossing the whiskers shows the median value. The composition of sediment derived from alkalic olivine basalt (AOB) in 10-KOK is shown for comparison.

Figure 6. Plots of chromium and nickel content relative to iron content for all samples. The dashed lines show the effects range median values (ERM) for reference.

Figure 7. Plots of total lead $(\mathrm{Pb})$ and iron $(\mathrm{Fe})$-normalized $\mathrm{Pb}$ contents of estuarine and reef fine sediment with distance offshore. Estuarine values are shown to the left of $0 \mathrm{~m}$. Dotted lines show marine background levels (Table 2). 